\title{
Crp-Like Protein Plays Both Positive and Negative Roles in Regulating the Pathogenicity of Bacterial Pustule Pathogen Xanthomonas axonopodis pv. glycines
}

\author{
Wei Guo, ${ }^{1}$ Jie Gao, ${ }^{1}$ Qingshan Chen, ${ }^{2}$ Bojun Ma, ${ }^{1}$ Yuan Fang, ${ }^{1}$ Xia Liu, ${ }^{1}$ Gongyou Chen, ${ }^{3, \dagger}$ and Jian-Zhong Liu ${ }^{1, \dagger}$ \\ ${ }^{1}$ Institute of Plant Genetics and Developmental Biology, College of Chemistry and Life Sciences, Zhejiang Normal University, Jinhua \\ 321004, China \\ ${ }^{2}$ College of Agriculture, Northeast Agricultural University, Harbin 150030, China \\ ${ }^{3}$ College of Agriculture and Biology, Shanghai Jiao Tong University, Shanghai 200240, China \\ Accepted for publication 4 February 2019.
}

\begin{abstract}
The global regulator Crp-like protein (Clp) is positively involved in the production of virulence factors in some of the Xanthomonas spp. However, the functional importance of $\mathrm{Clp}$ in $\mathrm{X}$. axonopodis pv. glycines has not been investigated previously. Here, we showed that deletion of $c l p$ led to significant reduction in the virulence of $X$. axonopodis pv. glycines in soybean, which was highly correlated with the drastic reductions in carbohydrates utilization, extracellular polysaccharide (EPS) production, biofilm formation, cell motility, and synthesis of cell wall degrading enzymes (CWDEs). These significantly impaired properties in the $c l p$ mutant were completely rescued by a single-copy integration of the wildtype $c l p$ into the mutant chromosome via homologous recombination. Interestingly, overexpression of $c l p$ in the wild-type strain resulted in significant increases in cell motility and synthesis of the CWDEs. To our
\end{abstract}

ABSTRACT surprise, significant reductions in carbohydrates utilization, EPS production, biofilm formation, and the protease activity were observed in the wild-type strain overexpressing $c l p$, suggesting that $\mathrm{Clp}$ also plays a negative role in these properties. Furthermore, quantitative reverse transcription polymerase chain reaction analysis suggested that $c l p$ was positively regulated by the diffusible signal factor-mediated quorumsensing system and the $\mathrm{HrpG} / \mathrm{HrpX}$ cascade. Taken together, our results reveal that $\mathrm{Clp}$ functions as both activator and repressor in multiple biological processes in $X$. axonopodis pv. glycines that are essential for its full virulence.

Keywords: Clp (Crp-like protein), Glycine max, positive and negative regulators, virulence, Xanthomonas axonopodis pv. glycines
The phytopathogens belonging to the genus Xanthomonas cause a variety of diseases in economically important plants worldwide (Büttner and Bonas 2010). These bacteria use quorum sensing (QS) or cell-to-cell communication mediated by diffusible signal factor (DSF) to regulate a diverse range of physiological activities contributing to virulence and adaptation of the pathogens in host plants (He and Zhang 2008; O'Connell et al. 2013; Ryan et al. 2015). DSF signals-mediated QS was firstly discovered and characterized in the black rot pathogen $X$. campestris pv. campestris (Barber et al. 1997; Wang et al. 2004). The biosynthesis, perception, and transduction of DSF signals in Xanthomonas spp. are executed by the proteins encoded by the regulation of pathogenicity factors (rpf) gene cluster. The $r p f F$, encoding an enoyl-coenzyme A hydratase, catalyzes the biosynthesis of DSF, whereas the products of $r p f C$ and $r p f G$ constitute a two-component regulatory system to sense and transduce the DSF signals (Slater et al. 2000; Ryan et al. 2006; Cai et al. 2017). In addition to RpfC, a novel DSF sensor RpfS, which is a PAS domain-containing histidine kinase, also functions in X. campestris pv. campestris (An et al. 2014). The DSF sensory system RpfC-RpfG is found in all xanthomonads, whereas

†Corresponding authors: J.-Z. Liu; jzliu@zjnu.cn, and G. Chen; gyouchen@sjtu.edu.cn

Funding: This work was supported by Natural Science Foundation of Zhejiang Province grant LY18C140004 and National Natural Science Foundation of China grants 31301633 and 31571423.

*The $e$-Xtra logo stands for "electronic extra" and indicates that ten supplementary figures and three supplementary tables are published online.

The author(s) declare no conflict of interest.

(c) 2019 The American Phytopathological Society the homologs of RpfS are only present in X. citri, X. axonopodis, and $X$. euvesicatoria and apparently absent from Xanthomonas species attacking monocots, such as $X$. oryzae and $X$. translucens (An et al. 2014; Guo et al. 2012b).

The cyclic dimeric GMP (c-di-GMP) is a conserved second messenger, which presents in all xanthomonads as well as in many other unrelated bacterial pathogens (Nesper et al. 2017; Zhang et al. 2013). The level of c-di-GMP is regulated by at least three categories of proteins containing GGDEF, EAL, or HD-GYP domains (Ryan et al. 2007; Zhou et al. 2013). The GGDEF proteins function as a diguanylate cyclase to synthesize c-di-GMP, whereas the HD-GYP and EAL proteins function as a phosphodiesterase to break the signal molecule c-di-GMP (Zhang et al. 2013; Zhou et al. 2013). RpfG contains a receiver domain for DSF signal transduction and an HDGYP domain for c-di-GMP degradation (Ryan et al. 2006; Slater et al. 2000). Through controlling the intracellular level of c-di-GMP, the congenital ligand of the global transcription factor Crp-like protein (Clp), RpfG modulates the regulatory activity of Clp (Leduc and Roberts 2009; Tao et al. 2010). In turn, the activated Clp modulates the expression of its target genes either directly by binding to their promoters via the recognition sites TGTGA-N6-TCACA or indirectly through the downstream transcription factor FhrR or Zur (Chin et al. 2010; He et al. 2007). As a result, it regulates diverse biological processes, including synthesis of cell wall degrading enzymes (CWDEs), extracellular polysaccharide (EPS) production, and cell motility, which are essential to the virulence and adaptation of Xanthomonas spp. (Guan et al. 2009; He et al. 2007). However, the homologs of FhrR are only present in $X$. campestris pv. campestris and apparently absent from the other Xanthomonas species, including the parenchyma pathogen $X$. axonopodis pv. glycines in soybean.

Genechip analysis revealed that only 94 of 299 genes regulated by Clp are subject to modulation by DSF signals in $X$. campestris 
pv. campestris strain XC1 (He et al. 2006, 2007), implying that Clp regulates gene expression not solely through the DSF signaling pathway. Conversely, it is possible that $c l p$ expression is modulated by additional signaling pathway(s). It has been reported that deletion of $c l p$ in strain XC1 resulted in a reduced EPS production and decreased activities of both cellulase and protease (He et al. 2007). However, relative to the wild-type strain, an increased protease activity was observed in the $c l p$ mutant of $X$. campestris $\mathrm{pv}$. campestris strain NRRLB1459 (de Crecy-Lagard et al. 1990). Inconsistent with the findings in $X$. campestris pv. campestris strain XC1, the Clp homolog in X. oryzae pv. oryzae strain PXO99A is not essential for DSF-mediated cellulase production (Guan et al. 2009). All of these findings indicate that different Clp homologs likely possess divergent functions among Xanthomonas spp. Although the global regulator Clp is well characterized in the vascular pathogens, such as X. campestris pv. campestris and $X$. oryzae pv. oryzae, the functions of Clp in the parenchyma pathogens, including $X$. axonopodis pv. glycines, are not well understood. Interestingly, our data showed that, compared with the $p g k$ (encoding a phosphoglycerate kinase) mutant, overexpressing $c l p$ in the $p g k$ mutant significantly reduced its ability in utilization of carbohydrates (unpublished data), implying that Clp of $X$. axonopodis pv. glycines is involved in carbohydrates utilization, a property that has not been reported for any of Clp homologs previously.

The Gram-negative bacterium $X$. axonopodis pv. glycines is the causal agent of bacterial pustule (BP), one of the most destructive diseases of soybean in several major soybean-producing countries (Athinuwat et al. 2009; Thowthampitak et al. 2008). The pathogen infects soybean leaves through stomata or wound sites and colonizes intercellular spaces in the mesophyll cells, resulting in small pale green spots with raised centers that develop into erumpent pustules (Chatnaparat et al. 2012). The disease progression caused by $X$. axonopodis pv. glycines infection is quite distinct from that of $X$. oryzae pv. oryzae and $X$. campestris pv. campestris, which invade the vascular system of their host plants. Although $X$. axonopodis pv. glycines seems to harbor some regulators of virulence factor production in common with $X$. oryzae pv. oryzae and $X$. campestris pv. campestris, such as the global regulator Clp, it seems likely that its distinct interactions with soybean would necessitate more diverse functions for Clp than those found in the vascular pathogens. Thus, in this study, we investigated the functional roles of Clp in regulating various biological processes to better understand its contributions to the pathogenicity of $X$. axonopodis pv. glycines. We provided evidence that $\mathrm{Clp}$ functions as both activator and repressor in multiple biological properties, which contribute to the full virulence and adaptation of this pathogen. Our data together with the results from other studies enable us to propose a working model to depict how Clp coordinates the DSF-mediated signals and the HrpG/HrpX signaling cascade that ultimately leads to the full virulence and adaptation of $X$. axonopodis pv. glycines.

\section{MATERIALS AND METHODS}

Bacterial strains and growth conditions. The bacterial strains and plasmids used in this study are listed in Supplementary Table S1. Escherichia coli strains were routinely grown in LB $(5 \mathrm{~g}$ liter ${ }^{-1}$ of yeast extract, $10 \mathrm{~g} \mathrm{liter}^{-1}$ of tryptone, and $10 \mathrm{~g} \mathrm{liter}^{-1}$ of $\mathrm{NaCl}$ ) medium at $37^{\circ} \mathrm{C}$. All $X$. axonopodis pv. glycines strains were grown at $28^{\circ} \mathrm{C}$ in NYG ( $3 \mathrm{~g} \mathrm{liter}^{-1}$ of yeast extract, $5 \mathrm{~g} \mathrm{liter}^{-1}$ of polypeptone, and $20 \mathrm{~g} \mathrm{liter}^{-1}$ of glycerol), NYG without glycerol (NY), NAN ( $1 \mathrm{~g} \mathrm{liter}^{-1}$ of yeast extract, $3 \mathrm{~g} \mathrm{liter}^{-1}$ of beef extract, and $5 \mathrm{~g}^{\text {liter }}-1$ of polypeptone), NAS (NAN with $100 \mathrm{~g} \mathrm{liter}^{-1}$ of sucrose), $\mathrm{NCM}\left[2 \mathrm{~g}\right.$ liter ${ }^{-1}$ of $\left(\mathrm{NH}_{4}\right)_{2} \mathrm{SO}_{4}, 4 \mathrm{~g}$ liter-1 of $\mathrm{K}_{2} \mathrm{HPO}_{4}, 6 \mathrm{~g}$ liter ${ }^{-1}$ of $\mathrm{KH}_{2} \mathrm{PO}_{4}$, and $0.2 \mathrm{~g} \mathrm{liter}^{-1}$ of $\mathrm{MgSO}_{4} \cdot 7 \mathrm{H}_{2} \mathrm{O}$ ], or $\mathrm{L}$ medium ( $10 \mathrm{~g} \mathrm{liter}^{-1}$ of tryptone, $5 \mathrm{~g}$ liter $^{-1}$ of yeast extract, $5 \mathrm{~g}$ liter ${ }^{-1}$ of $\mathrm{NaCl}$, and $1 \mathrm{~g} \mathrm{liter}^{-1}$ of glucose) when required (Guo et al. 2017).
Different antibiotics were added at the following final concentrations as required: carbenicillin, $60 \mu \mathrm{g} \mathrm{ml}^{-1}$; ampicillin, $60 \mu \mathrm{g} \mathrm{ml}^{-1}$; kanamycin, $25 \mu \mathrm{g} \mathrm{ml}^{-1}$; and spectinomycin, $100 \mu \mathrm{g} \mathrm{ml}^{-1}$.

Constructions of the $c l p$ deletion mutant, complementation, and $\boldsymbol{c l p}$-overexpressing strains. The in-frame deletion mutation of clp in $X$. axonopodis pv. glycines was generated following the method previously described (Jiang et al. 2009) using the primers listed in Supplementary Table S2. The obtained mutant strain was named $\mathrm{N} \Delta c l p$.

For complementation and overexpressing strains, the entire $c l p$ (including the promoter and coding regions) was amplified by polymerase chain reaction (PCR), and it was then cloned into pK18mobGII and pHM1 vectors, respectively. The resulting construction pKCclp and pCclp plasmids were then transferred into the mutant strain $\mathrm{N} \Delta c l p$ and the wild-type strain, respectively, via electrotransformation ( $\mathrm{Li}$ et al. 2011), resulting in the complemented strain in the mutant background named $\mathrm{CN} \Delta c l p$ and the $c l p$-overexpressing strain in the wild-type background named $X$. axonopodis pv. glycines ( $c l p)$.

Assays of carbohydrates utilization and EPS production. Qualitative/quantitative analysis of carbohydrates utilization was measured as previously described by Guo et al. (2015). EPS production assays were carried out according to the method described previously by Guo et al. (2017). Each experiment was repeated at least three times, and the data shown are the means of three replicates with standard deviation.

Determination of biofilm formation, cell motility, and exoenzyme activity. Biofilm assays were performed as described previously by Zhang et al. (2013). Swimming motility of $X$. axonopodis pv. glycines strains was investigated on semisolid medium plates with $0.3 \%$ agar as described by Guo et al. (2017). The exoenzyme activity in culture supernatants of $X$. axonopodis pv. glycines strains was analyzed according to the method described previously by Thowthampitak et al. (2008). The experiment was repeated independently three times, and the data presented are from a representative experiment.

Determination of ATP levels. Intracellular ATP levels were determined by using the ATP Assay Kit (Beyotime). Briefly, $X$. axonopodis pv. glycines strains were cultured in NY medium supplemented with $2 \%$ glucose for 12 or $24 \mathrm{~h}$, and the cells were subsequently harvested and immediately resuspended in ATP detection lysis buffer followed by collection of the supernatant and cooling in an ice bath. Measurements were done by addition of $100 \mathrm{ml}$ ATP detection working buffer to a 20-ml sample. All samples were measured at least in triplicate. Standard ATP curves were generated with standards containing known amounts of ATP in buffer.

Quantitative reverse transcription polymerase chain reaction. Quantitative reverse transcription polymerase chain reactions (qRT-PCRs) were performed using the primers. Briefly, the fresh $X$. axonopodis pv. glycines strains were incubated in NYG medium until the $\mathrm{OD}_{600}$ value reached 2.0; then, the bacterial cells were collected and washed twice with sterile water. Total RNAs were extracted using the Trizol reagent (Takara) according to the manufacturer's protocol; then, RNA samples were analyzed for quality using gel electrophoresis, and the potential traces of genomic DNA were removed using RNase-free DNase I (TaKaRa). Complementary DNA synthesis was conducted with AMV random primers provided by the manufacturer. qRT-PCRs were performed on the Applied Biosystems 7500 real-time PCR System using SYBR Premix ExTaq (Takara), and the PCR thermal cycle conditions were as follows: denature at $95^{\circ} \mathrm{C}$ for $30 \mathrm{~s}$ and 41 cycles at $95^{\circ} \mathrm{C}$ for $5 \mathrm{~s}$ and $60^{\circ} \mathrm{C}$ for $34 \mathrm{~s}$. Transcription of the integration host factor A (Thowthampitak et al. 2008) was used as an internal standard to estimate template concentrations. All qRT-PCRs were performed in two independent experiments with four replicates in each test. 
Plant assays. Assays for the virulence were performed as described previously (Chatnaparat et al. 2012). Briefly, Xanthomonas cells were grown in NYG medium at $28^{\circ} \mathrm{C}$ with constant shaking at $200 \mathrm{rpm}$ until the exponential phase of growth. Bacterial cells were harvested by centrifugation, washed twice, and resuspended in $1 \mathrm{mM}$ potassium phosphate buffer to $\mathrm{OD}_{600} \approx$ 0.2 . Bacteria were then inoculated onto soybean leaves (cultivar Suinong10; susceptible to BP, 6 weeks old) with high-pressure spray for virulence assessment. All plants were grown and maintained in a growth chamber as previously described (Chatnaparat et al. 2012). Plant phenotypes were scored 7 to 10 days postinoculation for pustule symptoms in soybean. Five plants were inoculated for each independent experiment, and each treatment was repeated at least three times.

Bacterial growth within soybean leaves was assessed as previously described by Guo et al. (2017). Briefly, bacterial cell suspensions $\left(\mathrm{OD}_{600} \approx 0.1\right)$ were infiltrated into the intercellular spaces of soybean leaves with needleless syringes. Leaves were collected daily for 7 days after infiltration and homogenized in $1 \mathrm{ml}$ of distilled water. Diluted homogenates were plated on NYG agar plates supplemented with appropriate antibiotics. The number of bacterial colonies was counted after incubation at $28^{\circ} \mathrm{C}$ until single colonies could be counted after 2 to 3 days. The experiments were repeated at least three times.

\section{RESULTS}

$X$. axonopodis pv. glycines Clp description and generation of the clp deletion mutant. Bioinformatic analysis of the $X$. axonopodis pv. glycines genome revealed the presence of a transcriptional regulator Crp homolog that is referred to as Clp hereafter. Clp belongs to Crp superfamily, and it is a protein of 230 amino acids with a predicted molecular mass of $25.6 \mathrm{kDa}$. Analysis of Clp with the Motif Scan Tool revealed that it contains a cNMP binding domain located in residues 22 to 127 and a Crp-type HTH domain from residues 158 to 230 . Clp shares 94 to $99 \%$ identity with the CAP-like protein from $X$. axonopodis pv. citri strain 306 and $X$. campestris pv. vesicatoria strain $85-10$ as well as a cAMPregulatory protein in $X$. campestris pv. campestris strain ATCC33913, X. oryzae pv. oryzae strain PXO99A, and X. oryzae pv. oryzicola strain BLS256. Using the Neural Network Promoter Prediction Website, the promoter sequence of $c l p$ was mapped at -79 to -128 nucleotides (with a score of 0.95 ) upstream of the start codon ATG.

To understand the functional roles of $c l p$, the $c l p$ deletion mutant (named $\mathrm{N} \Delta c l p$ ) was constructed by homologous suicide plasmid integration (Supplementary Fig. S1). As expected, a 1,533-bp fragment was amplified from the wild type with the primer pair $1 \mathrm{~F} /$ $2 \mathrm{R}$, whereas only a 840-bp DNA fragment was amplified in the $c l p$ mutant because of an in-frame deletion of $693 \mathrm{bp}$ from clp. The inframe deletion was further verified by a nested PCR using the primer pair 3F/3R. Meanwhile, the complemented and clpoverexpressing strains were also constructed by introducing the recombinant plasmids pKCclp and pCclp into $\mathrm{N} \Delta c l p$ and the wild type, respectively. The authenticities of these two strains were verified by antibiotic screening and PCR, respectively (Supplementary Fig. S2). The resulting complemented stain in the clp mutant background was designated as $\mathrm{CN} \Delta c l p$, and the clpoverexpressing strain in the wild-type background was designated as $X$. axonopodis pv. glycines $(\mathrm{clp})$. Whereas only one copy of $c l p$ was expressed in the complementation strain $\mathrm{CN} \Delta c l p$, multiple copies of $c l p$ were expressed in the $c l p$-overexpressing strain $X$. axonopodis pv. glycines $(\mathrm{clp})$.

The optimal level of $\mathrm{Clp}$ is required for carbohydrates utilization of $X$. axonopodis pv. glycines. In the presence of various carbohydrates, we found that overexpressing $c l p$ in the $p g k$ mutant significantly reduced the growth rate compared with that of the pgk mutant (unpublished data), implying that Clp might be involved in carbohydrate utilization of $X$. axonopodis pv. glycines. To explore whether mutation in $c l p$ affects carbohydrates utilization of $X$. axonopodis pv. glycines, the growths of $\mathrm{N} \Delta$ clp, $\mathrm{CN} \Delta c l p$, $X$. axonopodis pv. glycines (clp), and the wild-type strain were evaluated both qualitatively and quantitatively by the established methods (Guo et al. 2012a). The fact that the $c l p$ mutant grew similarly as well as the wild-type strain in NY medium (without carbohydrate) indicated that the clp mutant was not auxotrophic (Supplementary Fig. S3). However, on the NCM medium plates supplied with various sugars or pyruvate individually as the sole carbon source, the $c l p$ mutant strain grew significantly slower than the wild-type strain. The complemented strain CN $\Delta c l p$ formed similar colonies in sizes to those formed by the wild-type strain. Unexpectedly, instead of forming a larger colony, the clpoverexpressing strain $X$. axonopodis pv. glycines ( $\mathrm{clp}$ ) formed colonies significantly smaller in size compared with the ones formed by the wild-type strain, indicating that Clp is involved in regulating carbohydrates utilization in $X$. axonopodis pv. glycines.

To further confirm this result, the carbohydrates utilization of the four tested strains was measured quantitatively by growing them in liquid NCM medium in the presence of various carbohydrates followed by $\mathrm{OD}_{600}$ reading at different time points postinoculation. As shown in Figure 1, the growth rates reflected by the reading of $\mathrm{OD}_{600}$ were perfectly consistent with the colony sizes shown in Supplementary Figure S4, indicating that the tightly regulated optimal level of Clp is essential for $X$. axonopodis pv. glycines in efficiently utilizing carbohydrates. To investigate the effects of supplied carbohydrates on the expression of $c l p$, qRT-PCRs were performed to monitor its expression profiles. We found that the expression of $c l p$ was strongly inhibited by various sugars and pyruvate (Supplementary Fig. S5), suggesting that the expression of $c l p$ is negatively regulated by these carbohydrates.

Either knockout or overexpression of clp reduces EPS production in $X$. axonopodis pv. glycines. It has been reported that $\mathrm{Clp}$ is required for EPS production in $X$. campestris $\mathrm{pv}$. campestris and X. oryzae pv. oryzae (Guan et al. 2009; He et al. 2007). To explore whether Clp regulates the EPS production in $X$. axonopodis pv. glycines, EPS yields were measured both qualitatively and quantitatively. As shown in Supplementary Figure S6, on the NY medium plates with $2 \%$ glucose, sucrose, fructose, mannose, galactose, or pyruvate, the clp mutant and the $c l p$ overexpressing strain $X$. axonopodis pv. glycines ( $c l p)$ all formed significantly smaller colonies than the wild-type strain, suggesting that Clp is involved in regulating the EPS production of $X$. axonopodis pv. glycines.

To quantitatively evaluate the contribution of Clp to EPS production, all tested strains were cultured in NY medium supplemented with $2 \%$ carbohydrates for 5 days, and EPS was subsequently extracted from the cultures and quantified as described here. The results showed that the $c l p$ mutant produced $\sim 70$ to $90 \%$ less EPS than the wild-type strain when cultured in the NY medium supplemented with glucose, sucrose, fructose, mannose, galactose, or pyruvate (Fig. 2A). The complemented strain $\mathrm{CN} \Delta c l p$ could completely restore the EPS yield to the wild-type level. Interestingly, the $c l p$-overexpressing strain $X$. axonopodis pv. glycines ( $c l p$ ) displayed significantly reduced EPS production compared with that of the wild-type strain (Fig. 2A). These results indicate that either reduced or increased Clp level results in significantly reduced EPS yields, and the optimal level of Clp is essential for EPS production in X. axonopodis pv. glycines.

The EPS biosynthesis in Xanthomonas spp. is mainly controlled by the gum and xan gene clusters (Guo et al. 2017; Vojnov et al. 2001; Yang et al. 2016). To further understand how Clp regulates EPS biosynthesis in X. axonopodis pv. glycines, qRT-PCRs were performed to monitor the expression profiles of the genes in gum and xan clusters. As shown in Figure 2B, the transcriptional levels of the 12 genes in the gum cluster were all significantly decreased in the $c l p$ mutant compared with that in the wild-type strain, indicating that Clp plays a positive role in regulating the expression of gum 
genes. Additionally, the expressions of gumB and gumC were significantly lower in $X$. axonopodis pv. glycines $(\mathrm{clp})$ than that in the wild-type strain (Fig. 2B), further confirming that overexpression of $c l p$ also negatively regulates the expression of gumB and gumC. However, no effect of Clp on the expression of the xan genes was observed (Supplementary Fig. S7). These results suggest that the gum cluster, especially gumB and gumC, plays a critical role in EPS production of $X$. axonopodis pv. glycines.

The optimal level of Clp is critical for the biofilm formation in $X$. axonopodis pv. glycines. Biofilm is essential for bacterial virulence, and its formation requires the EPS xanthan (Danhorn and Fuqua 2007; Dow et al. 2003). To investigate whether Clp plays a role in biofilm formation in $X$. axonopodis pv. glycines, a biofilm formation assay was performed using a well-established method (Zhang et al. 2013). The biofilm formation was significantly reduced in the $c l p$ mutant strain compared with that of the wild-type strain (Fig. 3). The complemented strain $\mathrm{CN} \Delta$ clp could completely restore the biofilm formation to the wild-type level (Fig. 3 ). However, instead of complementing the biofilm formation to a higher than the wild-type level, overexpression of $c l p$ in the wildtype strain resulted in a comparable but reduced biofilm formation relative to the wild-type strain (Fig. 3), suggesting that an optimal Clp level is important for biofilm formation and that either an increased or decreased Clp level leads to compromised formation of biofilm in $X$. axonopodis pv. glycines.

Clp positively regulates cell motility of $X$. axonopodis $p v$. glycines. To explore whether mutation in $c l p$ affects cell motility of $X$. axonopodis pv. glycines, $\mathrm{N} \Delta c l p, \mathrm{CN} \Delta c l p, X$. axonopodis pv. glycines ( $c l p)$, and the wild-type strain were inoculated onto the tested plates for motility assay. As shown in Figure 4, all tested strains exhibited a comparable motility on the NY plates (Fig. 4A and B), whereas the $c l p$ mutant displayed a severely compromised
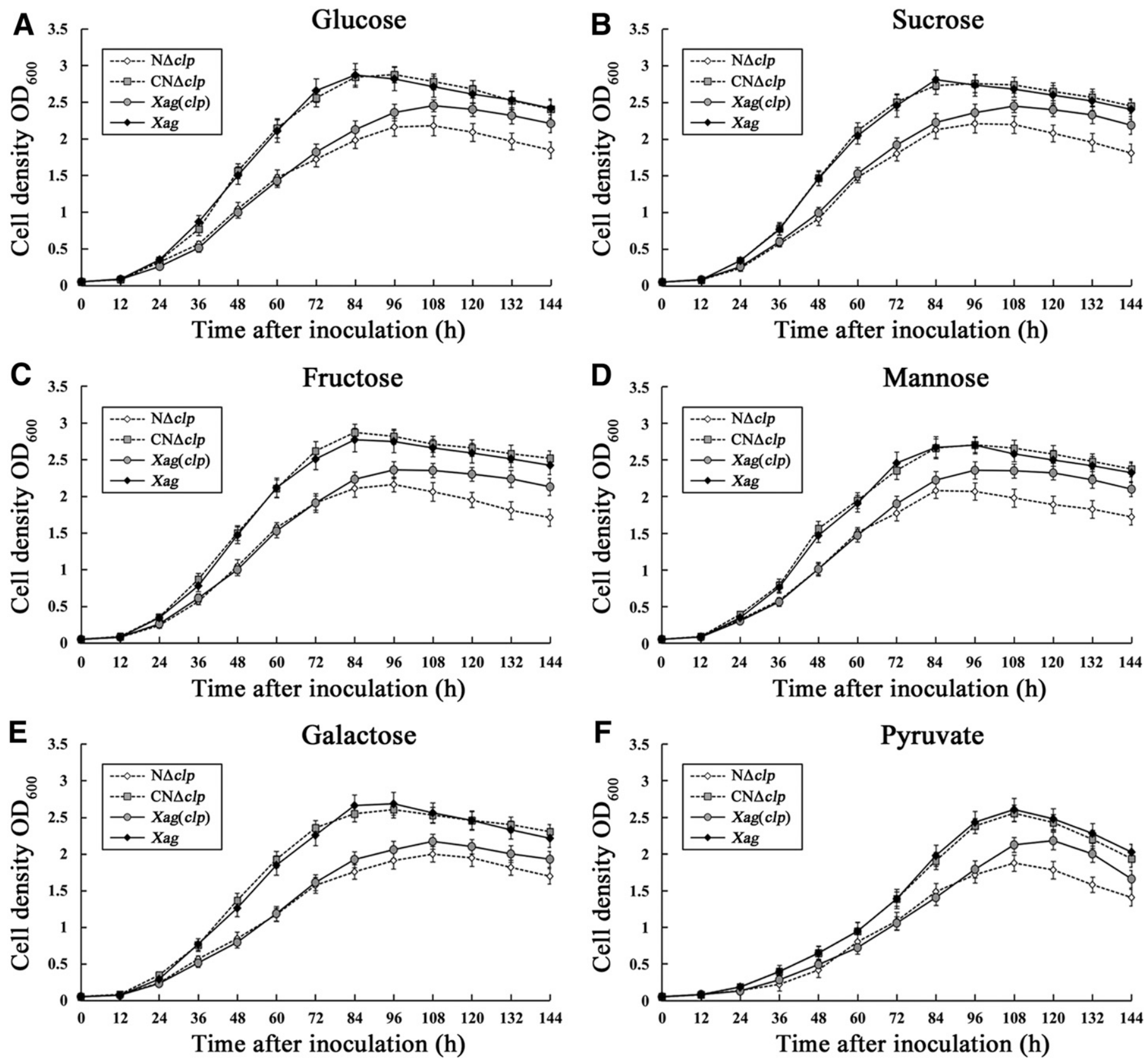

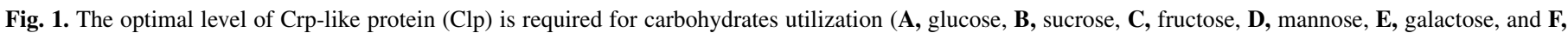

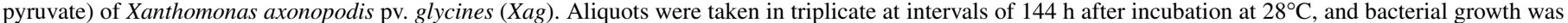
measured by $\mathrm{OD}_{600}$ readings. Data are means \pm standard deviations from three biological replicates. 
cell motility compared with the wild-type strain on NY containing $0.5 \%$ glucose plates (Fig. 4A and B). As expected, the defective motility of the $c l p$ mutant could be completely restored by the complementary plasmid pKCclp to the wild-type level (Fig. 4A and B). The $c l p$-overexpressing strain $X$. axonopodis pv. glycines (clp) showed cell motility to a level that higher than that of the wild-type strain (Fig. 4A and B). These results suggested that Clp plays a positive role in regulating cell motility of $X$. axonopodis pv. glycines.

To further understand how Clp regulates cell motility in $X$. axonopodis pv. glycines, qRT-PCRs were performed to monitor the expression profiles of five genes that have been shown to be vital for cell motility (Tian et al. 2015). The expressions of fliA (encoding an RNA polymerase sigma factor for flagellar), fleN (encoding a flagellar synthesis regulator), flhF (encoding a flagellar biosynthesis protein), rpoN2 (encoding an RNA polymerase sigma54 factor), and fle $Q$ (encoding a flagellar regulatory protein) were all significantly decreased in the clp mutant (Fig. 4C), indicating that the downregulation of these five genes was at least partly responsible for the reduced motility of the $c l p$ mutant. As expected, the transcriptions of these five genes, especially fliA and fleN, were significantly increased in the clp-overexpressing strain $X$. axonopodis pv. glycines (clp) (Fig. 4C). Together, these results suggest that Clp positively regulates cell motility, likely through regulating the expression of fliA, fleN, flhF, rpoN2, and fle $Q$ genes.

ATP provides the energy that drives the swinging of bacterial flagellum, and thus, it is important for bacterial motility (Lu et al. 2009a). To examine the affect of clp deletion on the intracellular ATP levels in $X$. axonopodis pv. glycines, we quantitated the ATP levels in both the wild-type and the $c l p$ mutant strains using the ATP Assay Kit (Beyotime). The ATP levels of the $c l p$ mutant strain were
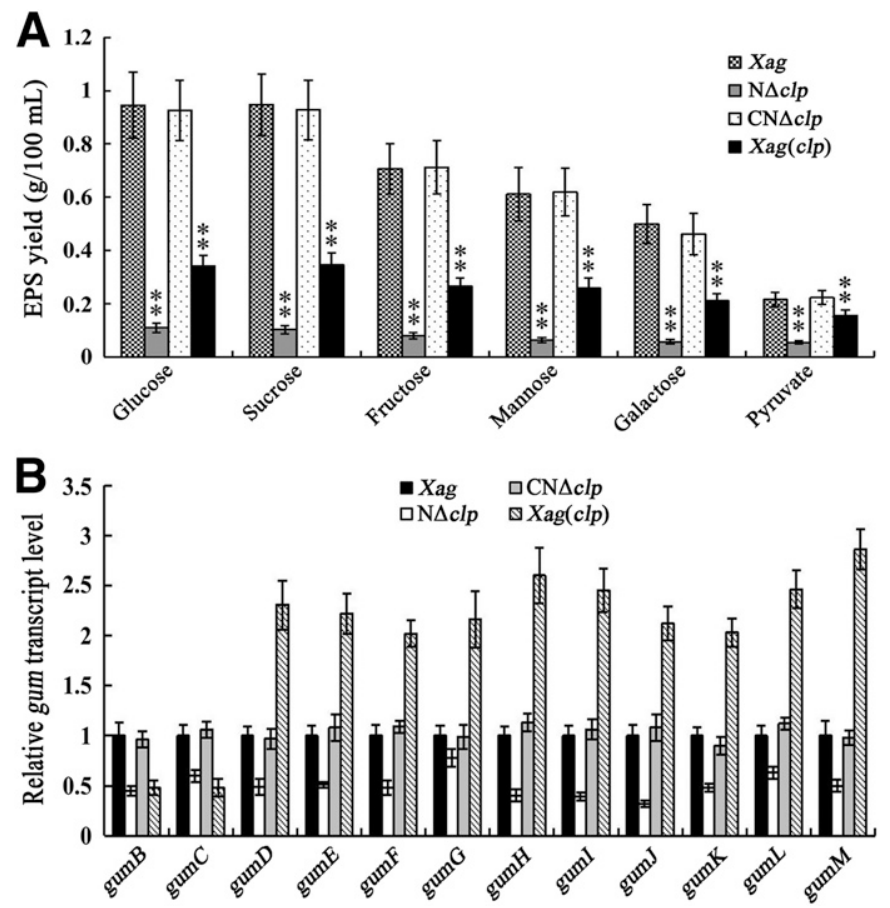

Fig. 2. A, Either knockout or overexpression of Crp-like protein ( $c l p)$ reduces extracellular polysaccharide (EPS) production in Xanthomonas axonopodis pv. glycines. All X. axonopodis pv. glycines strains were cultured in NY medium supplemented with $2 \%$ different carbohydrates for 5 days. The culture supernatants were collected for EPS production assays as described in the text. **Significant differences at $P=0.01$ by the Student's $t$ test. B, The expression levels of 12 gum genes were determined by quantitative reverse transcription polymerase chain reactions. Integration host factor A was used as a reference gene for normalization. Data are means \pm standard deviations from three biological replicates. Xag, X. axonopodis pv. glycines. $\sim 80.7$ and $\sim 76.9 \%$ of that of the wild-type strain when cultured in NY medium supplemented with $2 \%$ glucose for 12 and $24 \mathrm{~h}$, respectively, and the intracellular ATP level in the complemented strain was almost restored to the wild-type level (Fig. 4D), indicating that $c l p$ is required for the accumulation of intracellular ATP in X. axonopodis pv. glycines. Interestingly, instead of significantly increasing the intracellular ATP level, overexpressing $c l p$ in the wild-type strain slightly decreased the ATP levels (Fig. 4D), indicating that the optimal expression level of $c l p$ is required for maintaining the appropriate intracellular ATP level.

Either deletion or overexpression of $c l p$ reduces protease activity in $X$. axonopodis pv. glycines. It has been known that Clp possesses divergent functions on the protease activity of both strains XC1 and NRRLB1459 of X. campestris pv. campestris (Büttner and Bonas 2010; He et al. 2007). To explore whether deletion of $c l p$ affects protease activity in $X$. axonopodis $\mathrm{pv}$. glycines, the protease activity was determined in the wild-type, $\mathrm{N} \Delta c l p, \mathrm{CN} \Delta c l p$, and $X$. axonopodis pv. glycines (clp) strains. The protease activity is reflected by the size of the hydrolysis circle. As

A

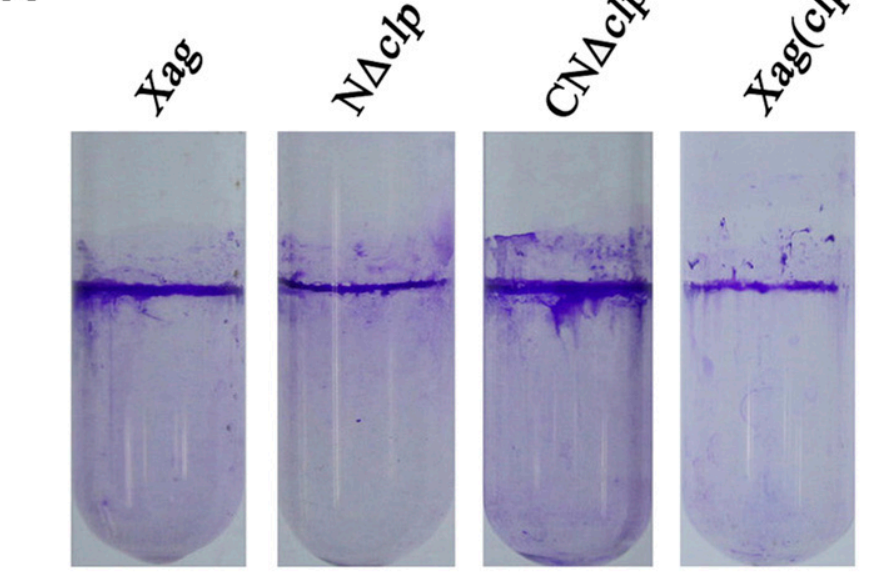

B

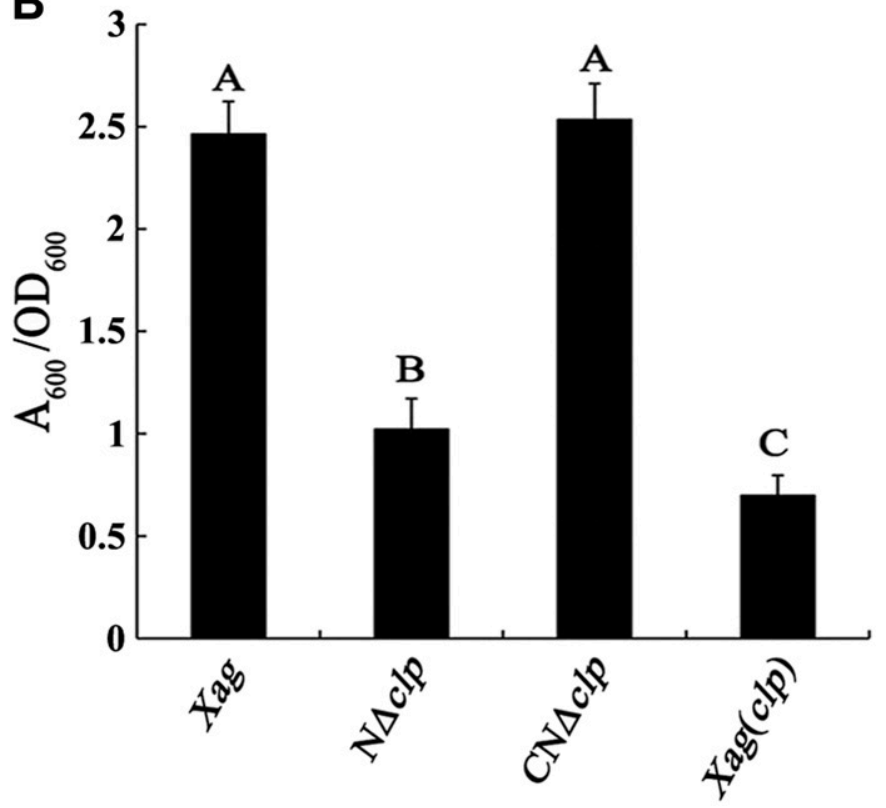

Fig. 3. The optimal level of Crp-like protein (Clp) is critical for the biofilm formation in Xanthomonas axonopodis pv. glycines. A, The glass-bound biofilm was stained with $0.1 \%$ crystal violet. $\mathbf{B}$, The biofilm is quantified as $A_{600} / \mathrm{OD}_{600}$. Data are means \pm standard deviations from three replicates. The different letters above horizontal columns represent significant differences at $P=0.01$ by the Student's $t$ test. Xag, X. axonopodis pv. glycines. 
expected, deletion of $c l p$ significantly compromised the protease activity (Fig. 5A and B). The reduced protease activity in the $c l p$ mutant was completely restored to the wild-type level by the complementary plasmid pKCclp (Fig. 5A and B). Interestingly, compared with that of the wild-type strain, the protease activity was also significantly reduced in the $X$. axonopodis pv. glycines (clp) strain overexpressing $c l p$ (Fig. 5A and B). These results indicated that Clp plays both positive and negative roles in regulating protease activity of $X$. axonopodis pv. glycines.

To further understand how Clp regulates the protease activities in $X$. axonopodis pv. glycines, qRT-PCRs were performed to monitor the expression profiles of 12 protease-related genes (Supplementary Table $\mathrm{S} 3$ ). As shown in Figure 5, the expression levels of pro 1-12 in N $\Delta c l p$ were all significantly reduced relative to the wild-type strain, indicating that the $c l p$ mutant universally represses the expression of pro1-12, which at least partially explains the reduced protease activities in $\mathrm{N} \Delta c l p$. The most significant reductions in the expression of pro1, pro2, pro3, and proll in the clp mutant suggest that these four genes likely contribute the most to the reduction of protease activities observed in the $c l p$ mutant (Fig. 5C). Although the expression levels of prol-4, pro8, prol0, and prol2 were significantly lower in $X$. axonopodis pv. glycines $(\mathrm{clp})$ than in the wild-type strain, the expression levels of pro5, pro6, pro7, pro9, and prol1 were significantly higher in $X$. axonopodis pv. glycines (clp) than in the wild-type strain, indicating that overexpression of $c l p$ plays opposite roles in regulating the expression of these two groups of genes (Fig. 5C).

Clp positively regulates synthesis of $\alpha$-amylase, endo$\beta$-mannanase, and carboxymethylcellulase in $X$. axonopodis pv. glycines. It has been shown that CWDEs contribute to disease symptomology by facilitating bacterial infection in Xanthomonas spp. (Thowthampitak et al. 2008; Zou et al. 2012). To explore whether deletion of $c l p$ also affects synthesis of the other exoenzymes in $X$. axonopodis pv. glycines, the activities of $\alpha$-amylase, endo$\beta$-mannanase, and carboxymethylcellulase were measured. Compared with the wild-type strain, synthesis of $\alpha$-amylase, endo- $\beta$-mannanase, and carboxymethylcellulase in the $c l p$ mutant strain was significantly decreased (Fig. 6A). As expected, the impaired exoenzymes activities in the $c l p$ mutant could be completely restored by the complementary plasmid pKCclp to the wild-type level (Fig. 6A). Overexpression of $c l p$ in the wild-type strain resulted in significantly increased activities of these exoenzymes (Fig. 6A). These results indicate that Clp positively regulates synthesis of $\alpha$-amylase, endo- $\beta$-mannanase, and carboxymethylcellulase in $X$. axonopodis pv. glycines.

To further understand how Clp regulates the activities of these exoenzymes in $X$. axonopodis pv. glycines, qRT-PCRs were performed to monitor the expression of the biosynthesis-related genes for these enzymes (amyl and amy 2 for $\alpha$-amylase; manA for endo- $\beta$-mannanase; and egl-1, egl-2, and engXCA for carboxymethylcellulase). Our results showed that the expression levels of these genes were highly correlated with the enzyme activities displayed in the wild type and the $c l p$ mutant strain as well as the complemented strain CN $\Delta c l p$ and $c l p$-overexpressing strain $X$. axonopodis $\mathrm{pv}$. glycines (clp) (Fig. 6B and C), indicating that Clp plays positive roles in regulating the expressions of the biosynthesis-related genes for these exoenzymes in $X$. axonopodis pv. glycines.

clp is positively regulated by the DSF-mediated QS system and the HrpG/HrpX cascade. RpfF, RpfC, and RpfG positively regulate the expression of $c l p$ in $X$. campestris $\mathrm{pv}$. campestris (He et al. 2007), and $\mathrm{HrpG}$ indirectly regulates the messenger RNA level of $c l p$ via GGDEF domain-containing proteins and c-di-GMP in $X$. axonopodis pv. citri (Guo et al.
A

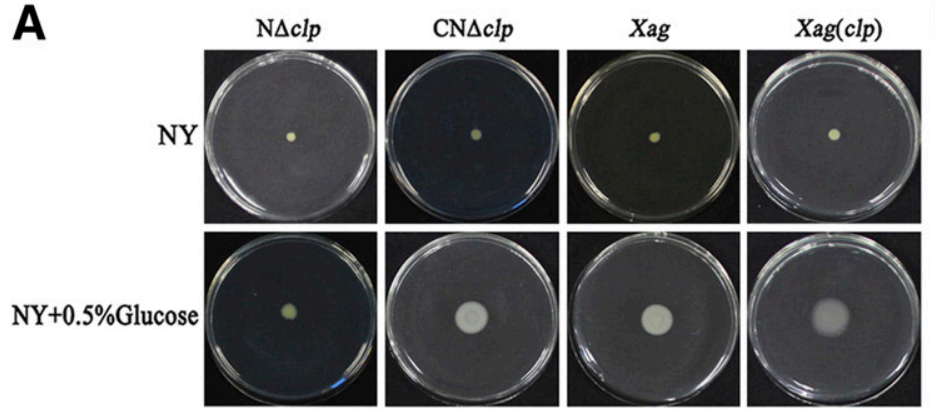

C

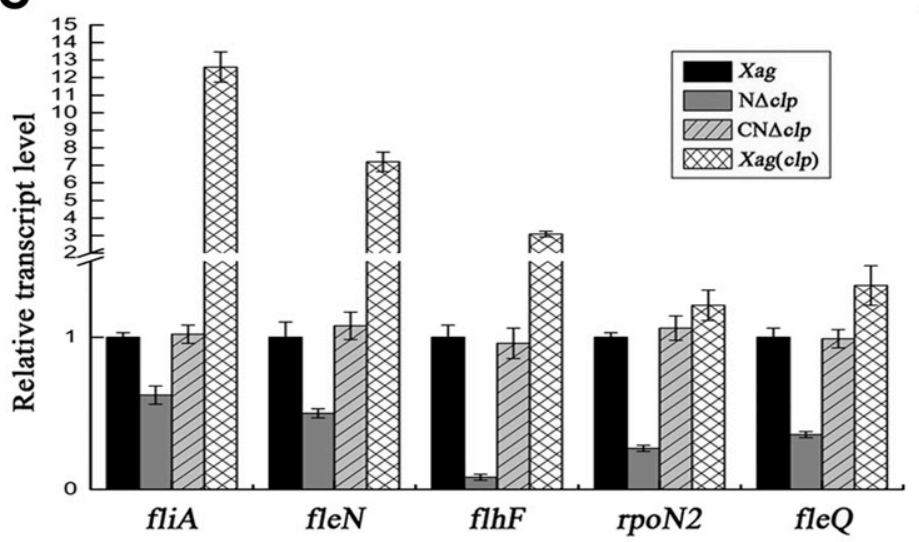

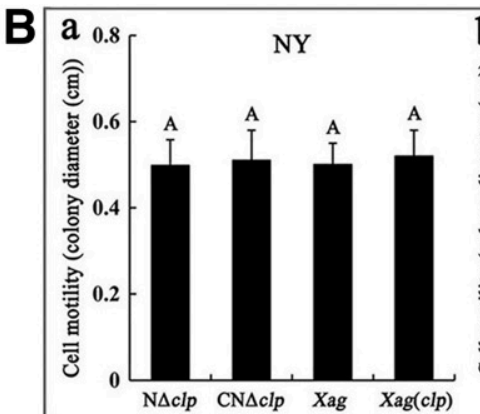

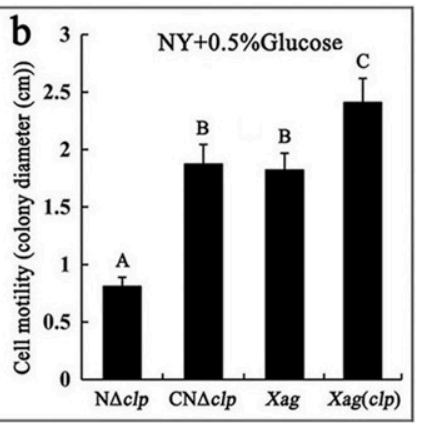

D

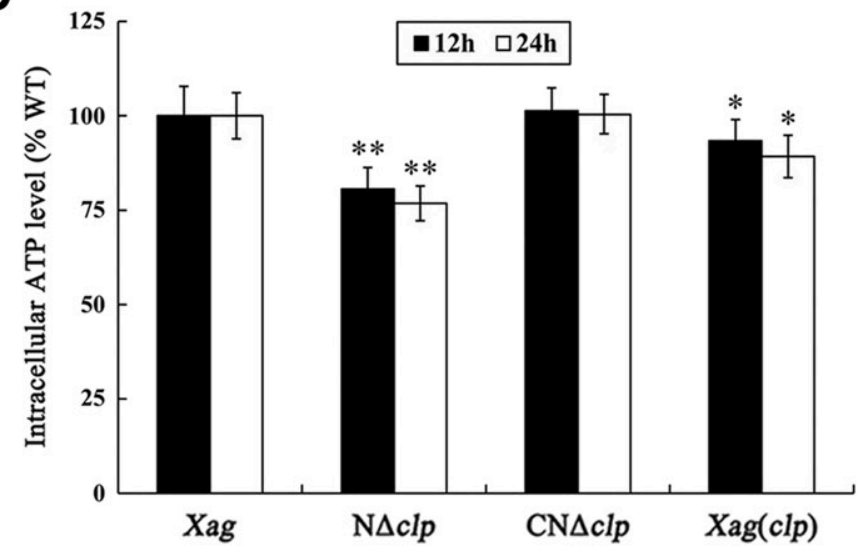

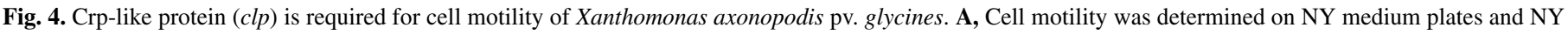

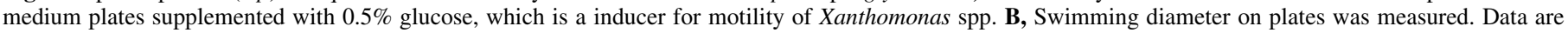

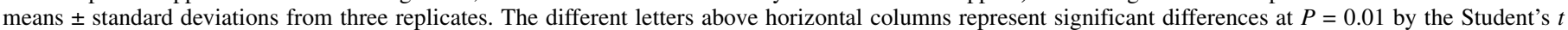

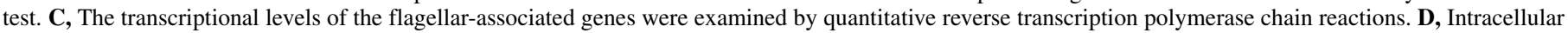

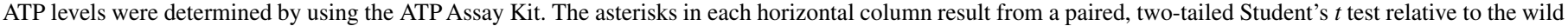
type. Xag, X. axonopodis pv. glycines. $* * P=0.01 ; * P=0.05$. 
2011). To explore whether $c l p$ expression is regulated by the DSFmediated QS system and the HrpG/HrpX cascade in X. axonopodis pv. glycines, qRT-PCRs were performed to examine its expression in different mutant strains. As shown in Figure 7A, the expression of $c l p$ was significantly downregulated in the $r p f F, r p f C, r p f G, r p f S$ (the second sensor for DSF signals), and $r p f R$ (encoding a putative
RpfS interplay protein) mutants (An et al. 2014), respectively. In addition, the expression of $c l p$ was also significantly reduced in $\mathrm{r} a v S$ and ravR mutants (both RavS and RavR are involved in the c-di-GMP signaling pathway) (Fig. 7A). These results indicated that the DSFmediated QS system positively regulates the expression of $c l p$. Mutations in trh, xopL (also called lrpX) (Islam et al. 2009), zur,
A

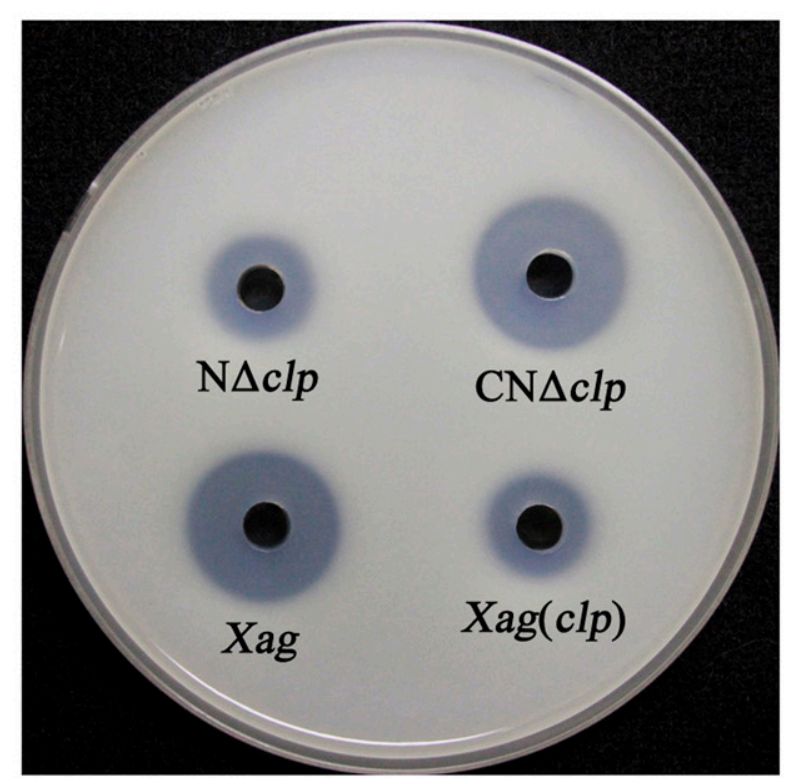

C
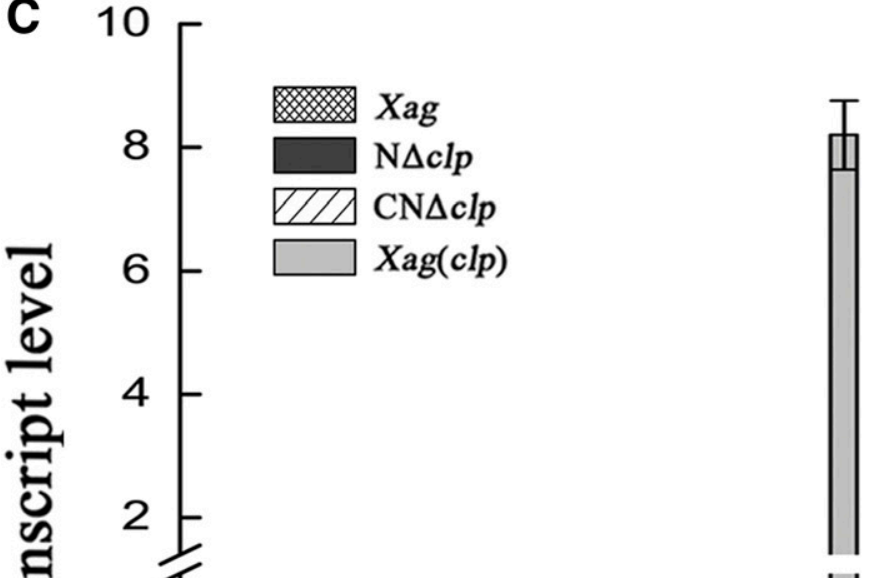

B

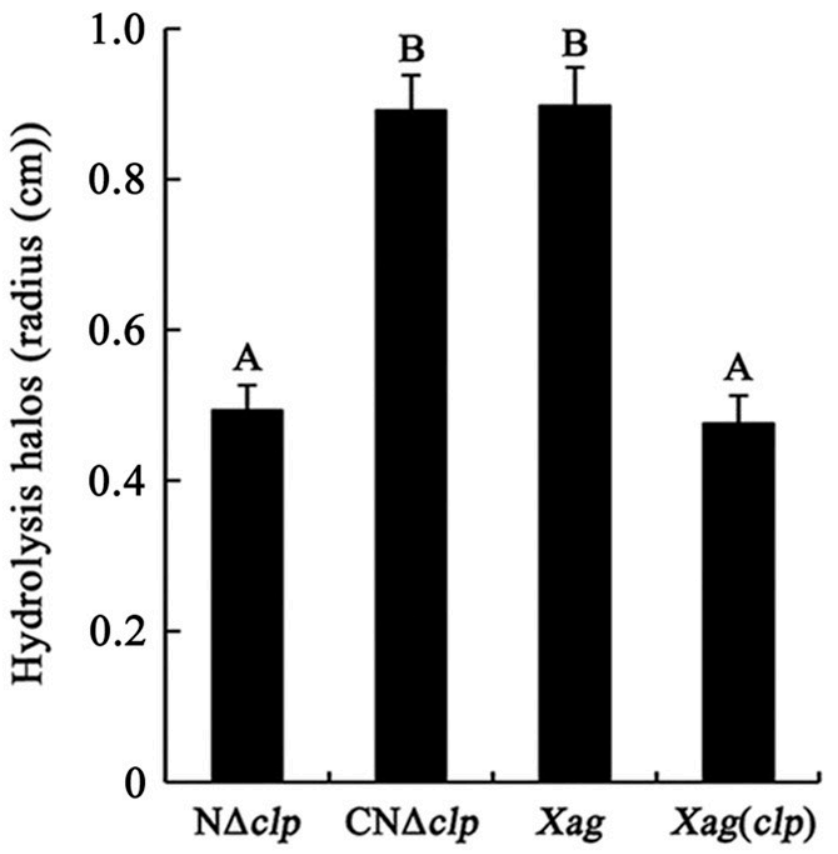

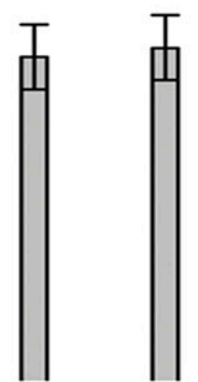
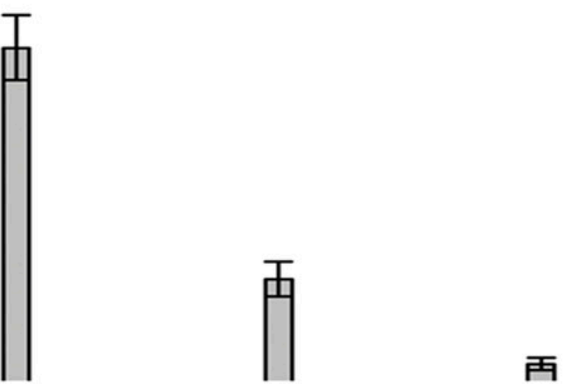

1.27

蛋 1.0

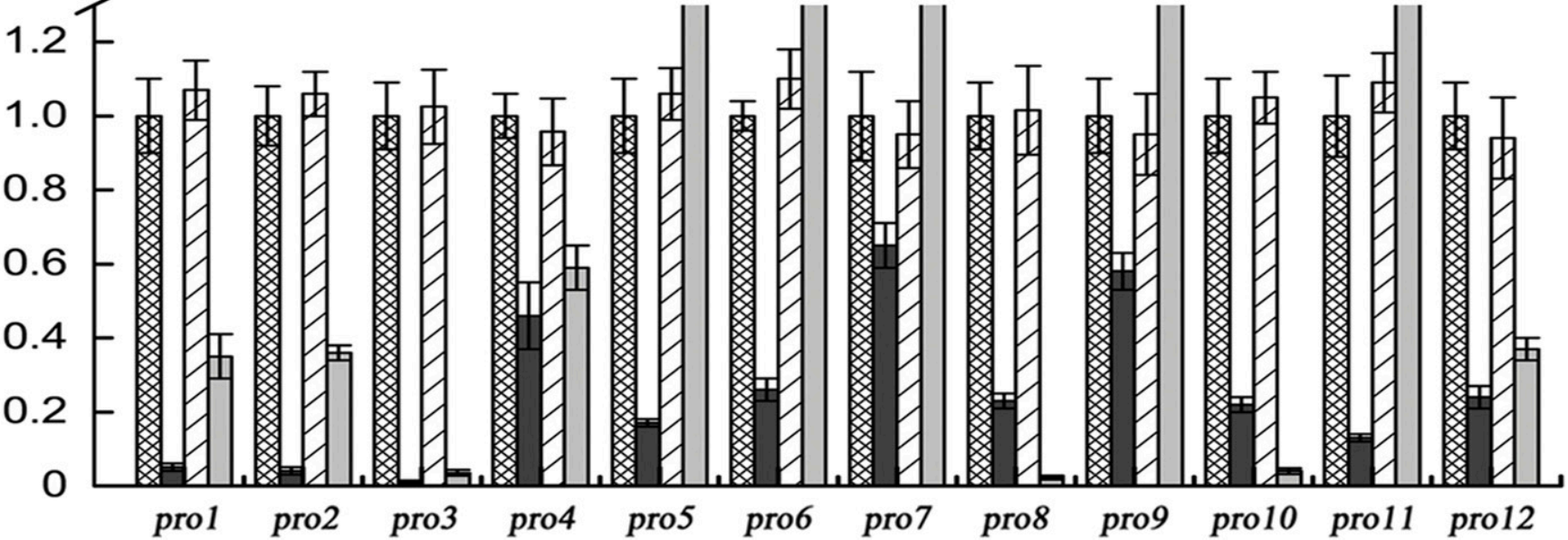

Fig. 5. Either knockout or overexpression of Crp-like protein (clp) reduces protease activity in Xanthomonas axonopodis pv. glycines. A, Protease activity was

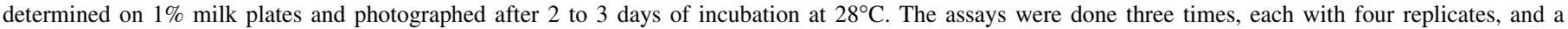

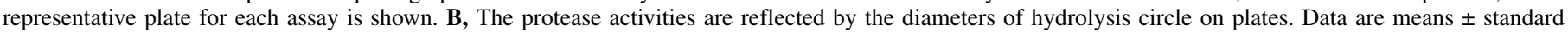
deviations from three replicates. The different letters above horizontal columns represent significant differences at $P=0.01$ by the Student's $t$ test. C, The

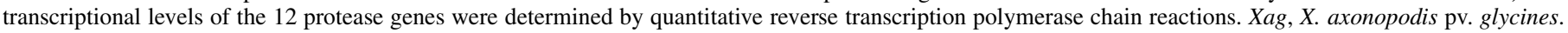


rsmA (a positive regulator of $h r p G$ ) (Andrade et al. 2014), $h r p X$, and $h r p G$, which are components of the HrpG/HrpX cascade, also reduced the expression of $c l p$, indicating that the $\mathrm{HrpX} / \mathrm{HrpG}$ cascade positively regulates the $c l p$ expression (Fig. 7B).

$c l p$ contributes to the full virulence of $X$. axonopodis $p v$. glycines in soybean. Because disruption of clp significantly impaired the multiple biological properties of $X$. axonopodis $\mathrm{pv}$. glycines, it prompted us to investigate whether Clp contributes to the virulence of $X$. axonopodis pv. glycines. As shown in Figure 8A, the $c l p$ mutant exhibited significantly reduced disease symptoms in soybean compared with those caused by the wild-type strain. The reduced disease symptom caused by the $\mathrm{N} \Delta c l p$ strain could be completely complemented by the complementary plasmid pKCclp (Fig. 8A). Interestingly, instead of increasing the disease symptom, overexpressing $c l p$ in the wild-type strain resulted in significant reductions in symptom severity relative to the wild-type strain (Fig. 8A). As a negative control, the T3SS deletion mutant $\mathrm{N} \Delta h r c \mathrm{C}$ did not cause any severe symptom in soybean (Fig. 8A). The disease symptom is usually affected by many factors, and thus, is not an accurate indicator for bacterial virulence. To accurately evaluate the effects of $c l p$ deletion and overexpression on the virulence of $X$. axonopodis pv. glycines, the bacterial growth assays were performed in soybean leaves for 7 days. As shown in Figure 8B, the bacterial growth rates at different time points were highly correlated with the
A

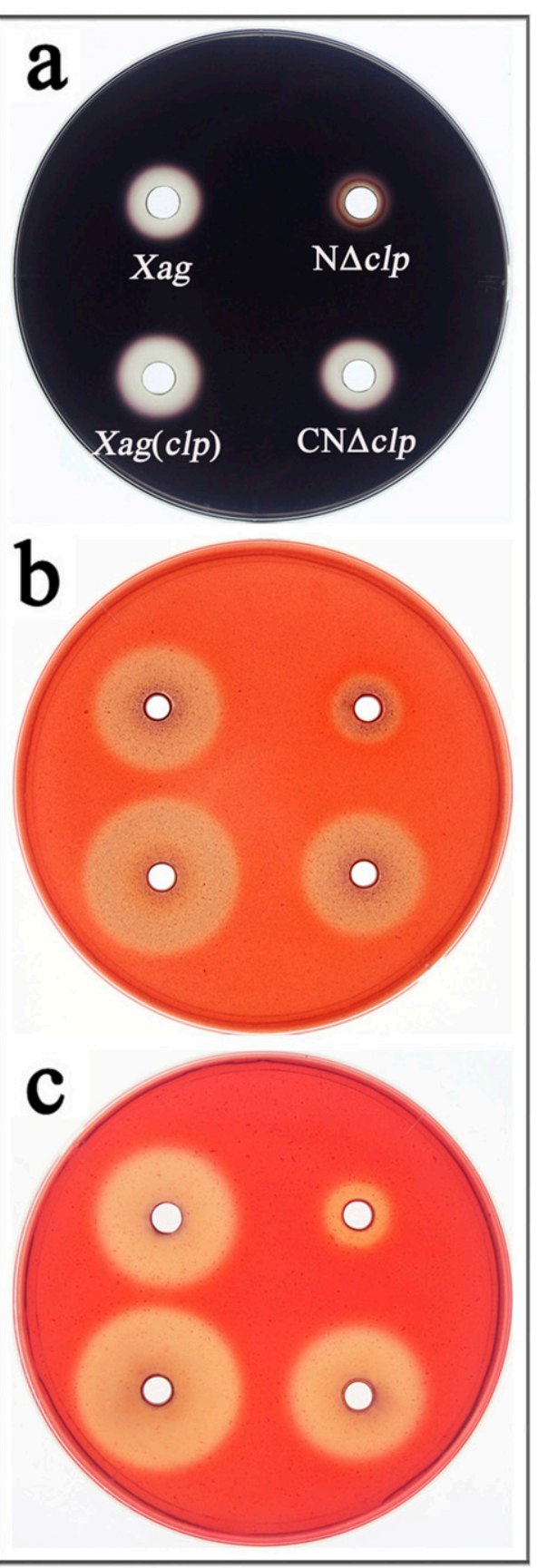

B

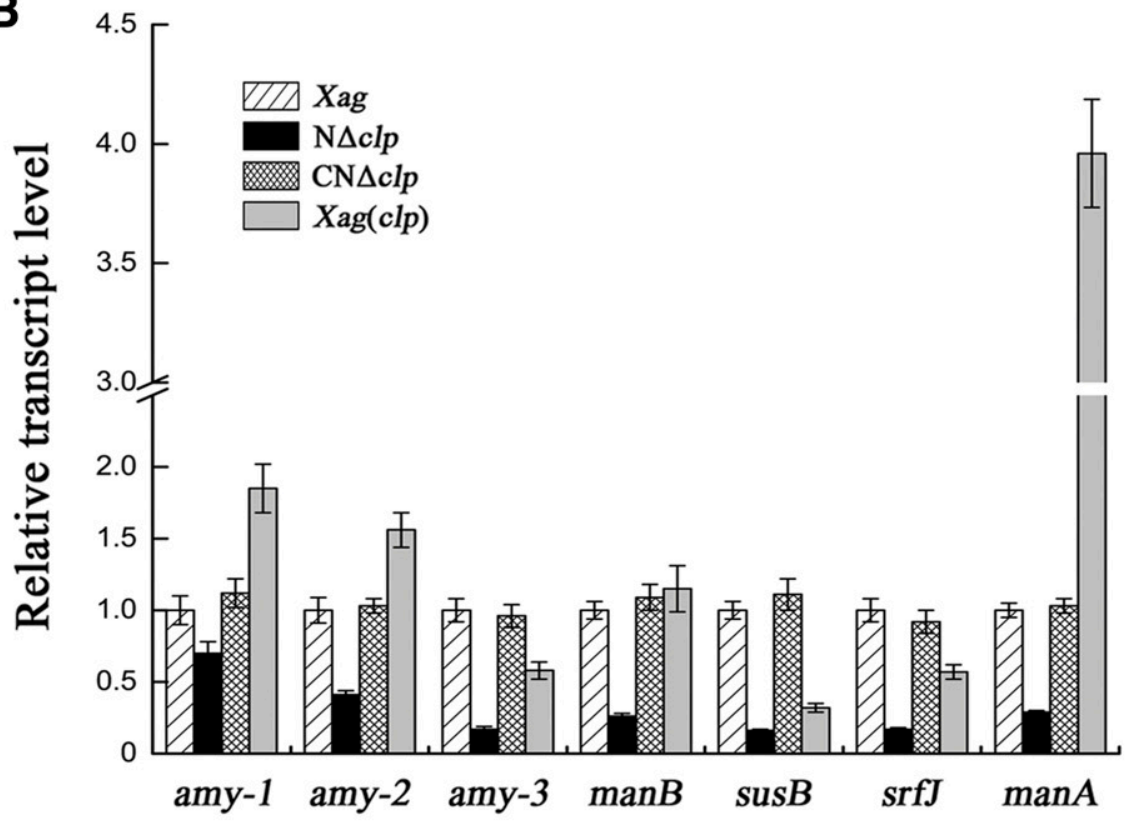

C

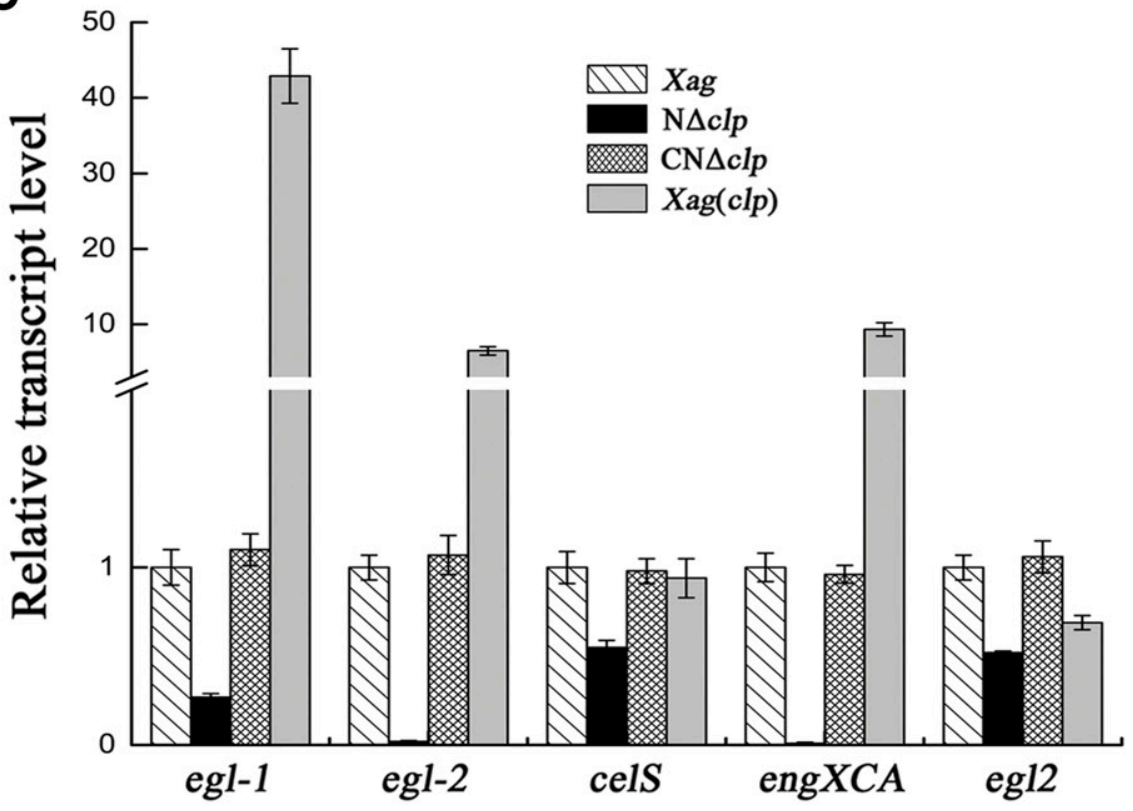

Fig. 6. Crp-like protein (Clp) positively regulates the synthesis of $\alpha$-amylase, endo- $\beta$-mannanase, and carboxymethylcellulase activity in Xanthomonas axonopodis pv. glycines. A, The activities of $\mathbf{a}, \alpha$-amylase, $\mathbf{b}$, endo- $\beta$-mannanase, and $\mathbf{c}$, carboxymethylcellulase were detected on plates and photographed after 2 to 3 days of incubation at $28^{\circ} \mathrm{C}$. The activity assays were done three times, each with four repeats, and a representative plate for each assay is shown. $\mathbf{B}$, The transcriptional levels of $\alpha$-amylase- and endo- $\beta$-mannanase-related genes were determined by quantitative reverse transcription polymerase chain reactions (qRT-PCRs). Data are means \pm standard deviations from three replicates. C, The transcriptional levels of the carboxymethylcellulase-associated genes were determined by qRT-PCRs. Xag, X. axonopodis pv. glycines. 
symptom severities for the tested strains, indicating that an optimal level of Clp is required for the full virulence of $X$. axonopodis pv. glycines. Either reduced or enhanced level of Clp has a negative impact on the full virulence of $X$. axonopodis pv. glycines.

\section{DISCUSSION}

In Xanthomonas spp., DSF-mediated QS or cell-to-cell communication plays an essential role in signal perception and signal transduction for coordinating the production of a range of virulence factors and biofilm dispersal. Clp, as a key component in DSFdependent signaling regulation, was first identified in the vascular pathogen $X$. campestris pv. campestris and found to positively regulate EPS production, cell motility, and cellulase and protease activities but not regulate biofilm dispersal (He et al. 2007). Clp was further reported to positively regulate EPS production and cell motility but not regulate biofilm formation and cellulase activity in the other vascular pathogen $X$. oryzae pv. oryzae (Guan et al. 2009). Furthermore, Clp was shown to negatively regulate protease activity in another strain of $X$. campestris pv. campestris (de Crecy-Lagard et al. 1990). In this study, we provided evidence that the global regulator Clp was positively regulated by the DSFmediated QS system and the HrpG/HrpX cascade and that it functions as both activator and/or repressor in carbohydrates utilization, EPS production, biofilm formation, cell motility, and synthesis of CWDEs of $X$. axonopodis pv. glycines. Compared with its counterparts in the vascular pathogens $X$. oryzae pv. oryzae and X. campestris pv. campestris (de Crecy-Lagard et al. 1990; Guan et al. 2009; He et al. 2007), the Clp homolog of the parenchyma pathogen $X$. axonopodis pv. glycines displays broader functions than those found in the vascular pathogens, possibly through the distinct interactions with its host soybean.

Consistent with the phenotypes on the plates, we found that Clp positively regulates carbohydrates utilization of $X$. axonopodis $\mathrm{pv}$. glycines (Fig. 1). Interestingly, the multicopy ( $\sim 15$ copies) complementation strain (in the $c l p$ mutant background) displayed decreased growth compared with the wild-type strain, implying that overexpression of clp probably attenuates the growth of $X$. axonopodis pv. glycines (data not shown). To confirm this, we overexpressed the $c l p$ in the wild-type background, and the $c l p$ overexpressing strain X. axonopodis pv. glycines ( $c l p$ ) shared similar growth rates both qualitatively and quantitatively as the multicopy complementation strain (Fig. 1), suggesting that the optimal Clp is essential for carbohydrates utilization in $X$. axonopodis pv. glycines. Similar to what has been observed for the pgi in $X$. campestris pv. vesicatoria, in which its expression is inhibited by its substrates (Guo et al. 2017), the expression of $c l p$ was significantly repressed by the carbohydrates, the utilization of which was either positively or negatively regulated by $c l p$. It is possible that the carbohydrates indirectly repress the expression of $c l p$ through the hrp system in the soybean pathogen $X$. axonopodis pv. glycines (Guo et al. 2011, 2012a). To our knowledge, it has not been previously shown that a Clp homolog participates in the regulation of carbohydrates utilization in Xanthomonas spp.

Similar to the clp mutant of the vascular pathogens $X$. campestris pv. campestris and X. oryzae pv. oryzae (Guan et al. 2009; He et al. 2007), deletion of $c l p$ in the parenchyma pathogen $X$. axonopodis pv. glycines resulted in significantly reduced EPS production (Fig. 2A). However, contrasting with that in $X$. campestris pv. campestris and $X$. oryzae pv. oryzae, the EPS production was significantly reduced in the $c l p$-overexpressing strain compared with the wildtype strain (Fig. 2A). The compromised expression of gum cluster (Fig. 2B), which is responsible for the EPS biosynthesis in Xanthomonas spp. (Vojnov et al. 2001; Yang et al. 2016), might account for the reduced EPS production in the clp mutant as well as in the $c l p$-overexpressing strain. The gum cluster ( $g u m B-M$ ) belongs to the transcribed polycistronic messenger RNAs or the same transcriptional unit, the promoter of which is located at the upstream gumB coding region. However, the opposite expression of gumB-M genes was observed, which could be caused by the presence of small promoters in the coding region (Lee et al. 2008; Yu et al. 2015). Additionally, the reduced carbohydrates utilization by the $c l p$ mutant and $c l p$-overexpressing strain probably could repress the pathogen to break down carbohydrates for energy and carbon molecules, both of which are also necessary for EPS production (Guo et al. 2017; Lu et al. 2009b).

Because of the unique regulatory characteristics of $X$. axonopodis pv. glycines Clp in the biosynthesis of EPS, which play an important
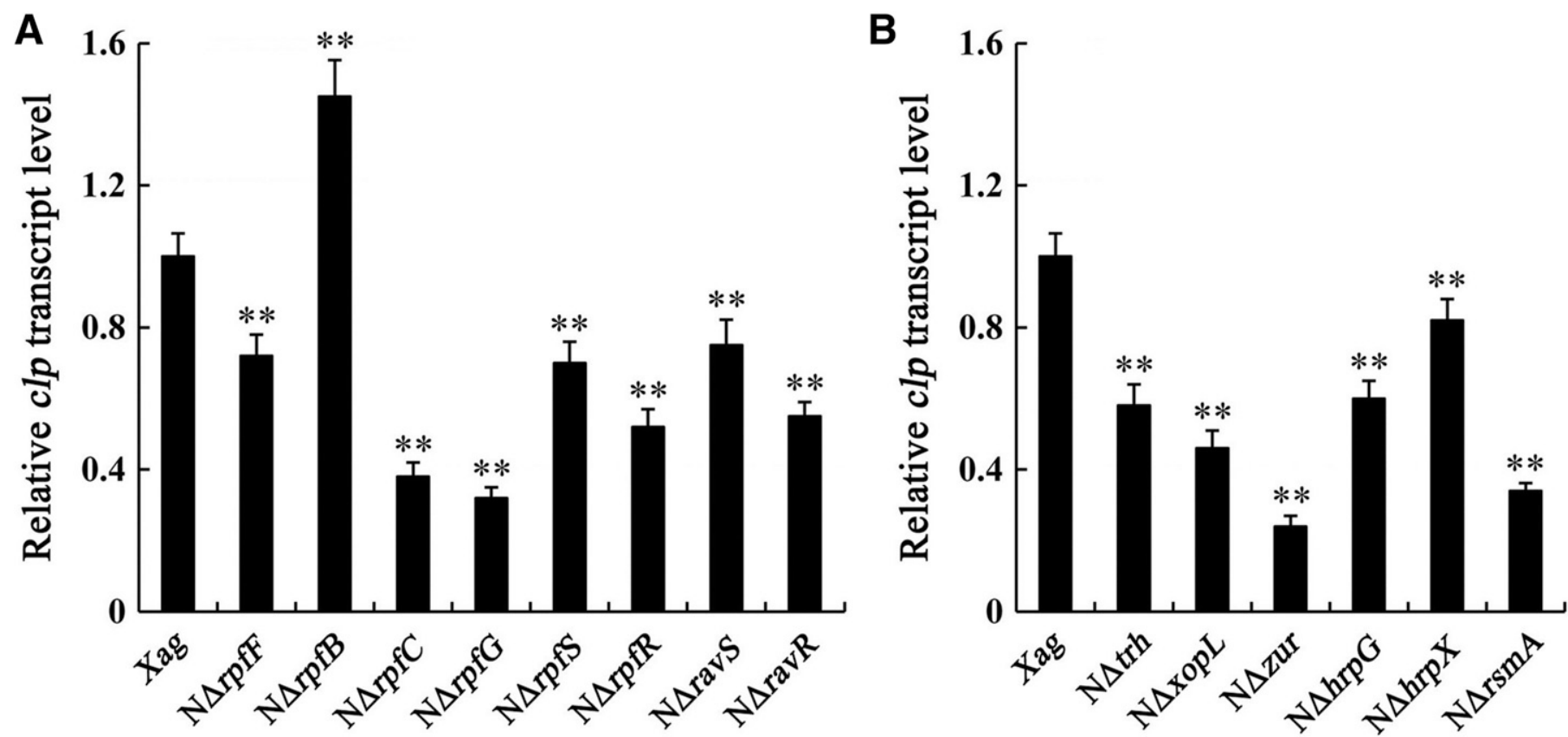

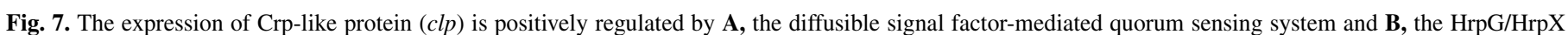

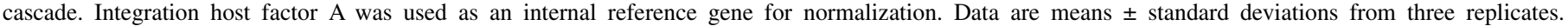
**Significant differences at $P=0.01$ by the Student's $t$ test. Xag, X. axonopodis pv. glycines. 
role in the formation of aggregates or biofilm (Dow et al. 2003), we were prompted to explore the roles for $X$. axonopodis pv. glycines $\mathrm{Clp}$ in regulating biofilm formation/dispersal. We found that, similar to EPS production, the $c l p$ mutant and the $c l p$-overexpressing strains both exhibit a decreased biofilm formation compared with the wild-type strain (Fig. 3). Interestingly, our results are inconsistent with the previous reports that Clp homologs from the vascular pathogen $X$. campestris pv. campestris and $X$. oryzae pv. oryzae are not involved in the regulation of DSF-dependent biofilm dispersal (Guan et al. 2009; He et al. 2007). The processes that regulate aggregate formation/dispersal by QS, such as DSF and $N$ AHLs, in plant pathogenic bacteria have not been defined yet, and the molecular mechanisms are probably different in each case (Davies et al. 1998; Dow et al. 2003; Zhang and Pierson 2001). It has been reported that both the gum and $x a g A B C D$ operons contribute to biofilm formation under different conditions, whereas the extracellular enzyme ManA disperse the aggregates in Xanthomonas spp. (Zhang et al. 2013; Zhou et al. 2013). Comparative genomic analysis reveals that only the gum operon and $m a n A$ are present (but the $x a g A B C D$ operon is not present) in the genome of $X$. axonopodis pv. glycines. The compromised expression of gum cluster (Fig. 2B) and manA (Fig. 6B) might account for the reduced biofilm formation in the $c l p$ mutant as well as in the $c l p$-overexpressing strain.

The contribution of flagellar motility to the pathogenesis of bacterial pathogens of plants varies in different species. Flagellar motility seemed to be required for biofilm formation and pathogenicity of $X$. axonopodis pv. citri, the causative agent of citrus canker (Malamud et al. 2011). However, flagellar motility might not be essential for the virulence of the vascular pathogen $X$. oryzae pv. oryzae (Tian et al. 2015). The probable reason for this is that bacterial cells are nonmotile after they are inside of the host xylem (Tans-Kersten et al. 2004). We found that deletion of clp in $X$. axonopodis pv. glycines resulted in significantly reduced cell motility, whereas overexpressing $c l p$ in the wild-type strain significantly increased the cell motility (Fig. 4A and B). The decreased or increased motility was highly correlated with the expressions of fliA, fleN, flhF, rpoN2, and fle $Q$ (Fig. 4C), which are required for swimming motility (Tian et al. 2015). The reduced cell motility was also observed in the $c l p$ mutant of $X$. oryzae pv. oryzae strain PXO99A (Guan et al. 2009), indicating a conserved function for $c l p$ in cell mobility between these two species. We also presented additional evidence that the level of intracellular ATP, which provides the energy for cell motility ( $\mathrm{Lu}$ et al. 2009a), was
A

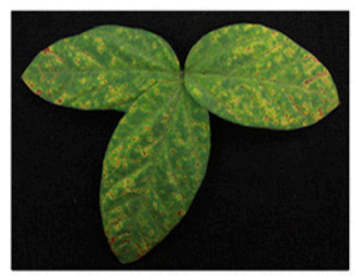

Xag

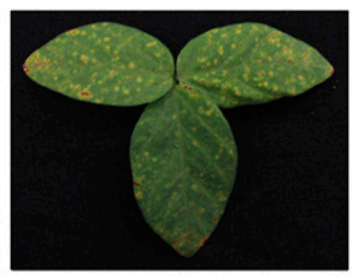

Xag (clp)

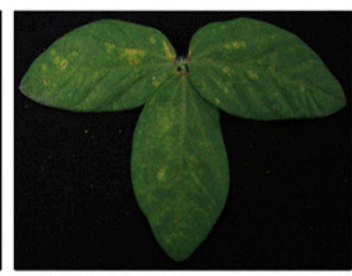

$\mathrm{N} \Delta \mathrm{clp}$

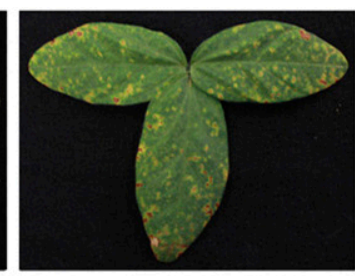

$\mathrm{CN} \Delta \mathrm{clp}$

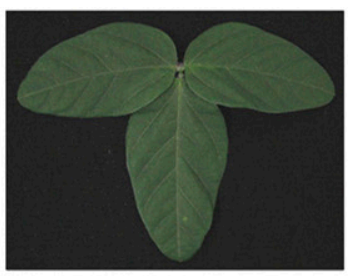

$\mathrm{N} \Delta h r c C$

B

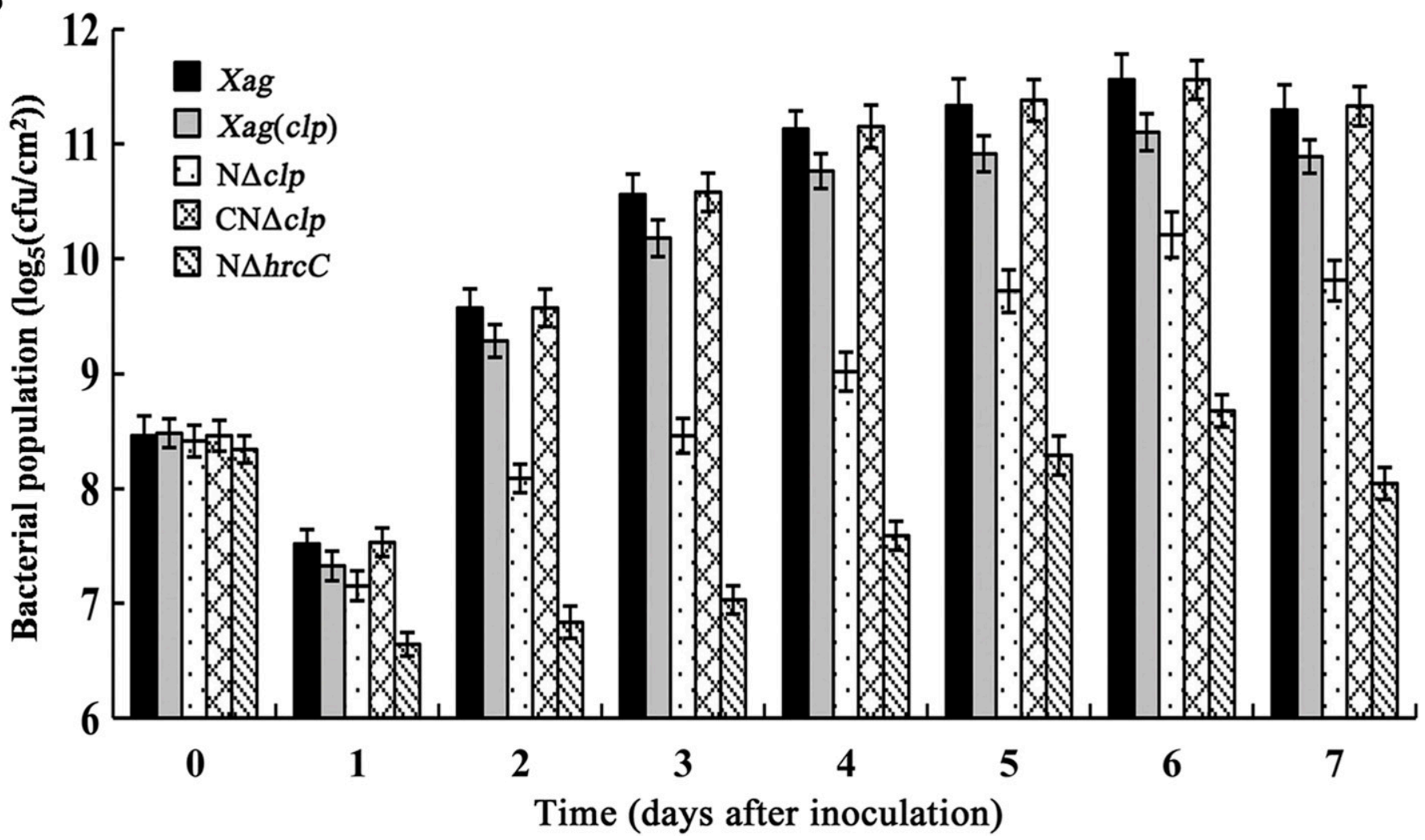

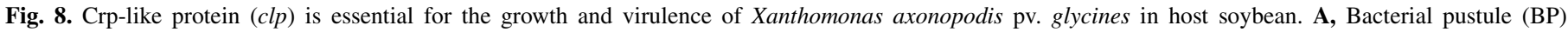

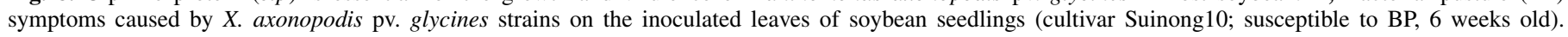

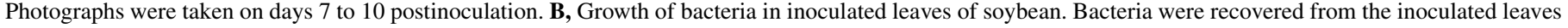
at different days postinoculation. Data are means \pm standard deviations from three replicates. Xag, X. axonopodis pv. glycines. 
significantly reduced in the clp mutant compared with in the wildtype strain (Fig. 4D). The reduced ATP level may be one of the major findings that negatively affects cell motility in the clp mutant. However, whether flagellar motility contributes to the pathogenicity of $X$. axonopodis pv. glycines remains to be investigated in the future.

Clp positively regulates the biosynthesis of CWDEs (Fig. 6A) and negatively regulates protease activity of $X$. axonopodis $\mathrm{pv}$. glycines (Fig. 5A). These positive and negative roles of Clp are corroborated perfectly by the correlations between levels of $c l p$ and the expression levels of corresponding pathway genes in different strains (Fig. 5C; Fig. 6B and C). It has been reported that the regulation of $\mathrm{Clp}$ in the biosynthesis of extracellular enzymes differs significantly among different Xanthomonas spp. For example, deletion of $c l p$ in $X$. campestris pv. campestris strain $\mathrm{XC} 1$ resulted in decreased cellulase activity and protease activity (He et al. 2007), whereas the clp mutant in X. oryzae pv. oryzae strain PXO99A did not affect the cellulase activity (Guan et al. 2009), and deletion of $c l p$ in X. campestris pv. campestris strain NRRLAB1459 led to increased protease activity (de Crecy-Lagard et al. 1990). In addition, the presence of some extracellular enzymes or activities seems to be significantly distinct in different xanthomonads. For example, EngXCA is a major cellulase in $X$. campestris pv. campestris (Schröter et al. 2001) but not in X. citri subsp. citri 29-1 strain (Xia et al. 2016), and the protease activity exists in X. oryzae pv. oryzae strain T7174R (Lu et al. 2011) but not in $X$. oryzae pv. oryzae strain PXO99A (Zhou et al. 2013).

As expected in $X$. campestris pv. campestris and $X$. axonopodis pv. citri (Guo et al. 2011; He et al. 2007), the expression of $c l p$ in $X$. axonopodis pv. glycines is positively regulated by the DSFmediated QS system and the HrpG/HrpX cascade in the rich NYG medium (Fig. 7A and B). In addition, the expression of clp is also positively regulated by the HrpG/HrpX cascade in apoplastmimicking XVM2 medium and soybean sap (Supplementary Fig. S8). All of these results suggested a possibility that similar upstream regulatory mechanisms may exist among the three strains for $c l p$ expression. In the $X$. campestris pv. campestris ATCC33913 strain, the promoter region of $c l p$ contains a putative DNA binding site GATGA-N6-CCACA (cutoff score $=0.7$ ) $($ He et al. 2007), which could be specially recognized by $\mathrm{Clp}$, indicating that $c l p$ might be regulated directly by itself. However, sequence analysis revealed that the promoter region of $c l p$ in $X$. axonopodis pv. glycines does not contain such a DNA binding site. Furthermore, the GUS activity assay also revealed that the expression of $c l p$ was not self-regulated in X. axonopodis pv. glycines (Supplementary Fig. S9), indicating that the regulation of $c l p$ expression between $X$. axonopodis pv. glycines and $X$. campestris pv. campestris could be different. It is worth mentioning that the optimal level of Clp is necessary for maintaining both the virulence and the growth in planta for $X$. axonopodis pv. glycines (Fig. 8). The attenuation in virulence and growth of either the knockout or the $c l p$ overexpression strain in soybean leaves may have resulted, at least partially if not completely, from the combined effects of the compromised carbohydrates utilization (Fig. 1) and EPS production (Fig. 2A), reduced protease activities (Fig. 5A), and the Clp-dependent cell motility (Fig. 4A) as well as the impaired CWDEs synthesis (Fig. 6A). Nutrient utilization is essential for the pathogen to grow and colonize within the host cells (Mellgren et al. 2009; Tang et al. 2005). Therefore, the reduced ability of either the $c l p$ knockout or overexpression strain to utilize available carbohydrates in the host reduces its growth and aggressiveness. Consistent with this, we have previously shown that the $z w f$ (encoding glucose-6-phosphate dehydrogenase) and pgi (encoding glucose 6-phosphate isomerase) mutants in X. campestris pv. vesicatoria, both of which lose the capability to utilize hexose or pyruvate as the sole carbon sources, have limited growth in host tissues and significantly reduced the virulence (Guo et al. 2015, 2017). EPS has been shown to act as an important virulence factor that plays a prominent role during pathogen infection in Xanthomonas spp. (Guo et al. 2015; Yang et al. 2007). It can enhance the susceptibility of the host plant by suppressing defense responses, such as callose deposition (Yun et al. 2006), mask the bacterium to prevent recognition by the host (Alvarez 2000), and contribute to biofilm formation (Dow et al. 2003). It has been shown that inactivation of the glyceraldehyde-3phosphate dehydrogenase, which can result in reduction of EPS production, significantly reduced the virulence of $X$. campestris $\mathrm{pv}$. campestris (Lu et al. 2009b). It was also reported that cell motility makes a contribution to the invasion and colonization of the pathogen and the development of disease symptom (Guo et al. 2015; Lu et al. 2009a). Although the relationship between cell motility and virulence has not been specifically reported, cell motility and virulence factor EPS could have crosstalk (Lu et al. 2009a). Thus, we speculate that cell motility could contribute to the full virulence of Xanthomonas spp. to a certain degree. CWDEs secreted by the type II secretion system are essential for pathogens in virulence (Wang et al. 2008; Zou et al. 2012). During pathogenesis, plant cell walls act as the first barrier of defense against bacterial invasion and multiplication. The enzymatic activities of CWDEs may facilitate pathogen invasion into the cells of its host plants by digesting plant cell structures, thus contributing to disease development (Xia et al. 2016; Zou et al. 2012). The intensity of extracellular protease activity in bacterial leaf streak pathogenic strains has been used as an indicator for virulence assessment in rice (Zou et al. 2012). Consistent with this, it has been shown that EcpA, an extracellular protease, is a specific virulence factor required by the parenchyma pathogen $X$. campestris pv. vesicatoria (Zou et al. 2012).

Our data together with the results from other studies enable us to propose a working model to depict how Clp coordinates the DSFmediated signals and the HrpG/HrpX signaling cascade that ultimately regulate multiple biological properties. In this model (Supplementary Fig. S10), DSF signals generated by RpfF are transduced through the RpfC sensor to the RpfG response regulator via a conserved phosphorelay mechanism (Cai et al. 2017; Ryan et al. 2006; Slater et al. 2000). Through controlling the intracellular level of c-di-GMP, the congenital ligand of the global transcription factor Clp, RpfG modulates the regulatory activity of Clp (Leduc and Roberts 2009; Tao et al. 2010). Parallel to RpfC/RpfG twocomponent regulatory system, the RpfS/RpfR system also could sense and transduce DSF signals (An et al. 2014). Additionally, the RavS/RavR system senses and transduces low-oxygen signals (He et al. 2009), and HrpX/HrpG system transduces environmental signals recognized by an unidentified receptor or sensor (Zhang et al. 2009). All of these signals converge on and positively regulate the $c l p$ expression or activity. As a consequence, the increased level of $c l p$ and/or activated Clp results in altered expressions of multiple clusters of downstream genes and ultimately, modulates numerous biological processes, such as carbohydrates utilization, EPS production, biofilm formation, cell motility, and synthesis of extracellular enzymes, which are essential for the full virulence and adaptation of the parenchyma pathogen $X$. axonopodis pv. glycines in soybean. The convergence and integration of various signals to the global regulator $\mathrm{Clp}$ enable $X$. axonopodis pv. glycines to coordinate these signals and respond to the external changes with high efficiency and great flexibility. In sum, our study has significantly advanced the understanding of the roles for the global regulator Clp of Xanthomonas spp.

\section{LITERATURE CITED}

Alvarez, A. M. 2000. Black rot of crucifers. Pages 21-52 in: Mechanisms of Resistance to Plant Diseases. A. J. Slusarenko, R. S. S. Fraser, and L. C. van Loon, eds., Kluwer Academic Publications, Dordrecht, The Netherlands

An, S. Q., Allan, J. H., McCarthy, Y., Febrer, M., Dow, J. M., and Ryan, R. P. 2014. The PAS domain-containing histidine kinase RpfS is a second sensor for the diffusible signal factor of Xanthomonas campestris. Mol. Microbiol. 92:586-597. 
Andrade, M. O., Farah, C. S., and Wang, N. 2014. The post-transcriptional regulator $r s m A / c s r A$ activates T3SS by stabilizing the $5^{\prime} \mathrm{UTR}$ of $h r p G$, the master regulator of $h r p / h r c$ genes, in Xanthomonas. PLoS Pathog 10: e1003945

Athinuwat, D., Prathuangwong, S., Cursino, L., and Burr, T. 2009. Xanthomonas axonopodis pv. glycines soybean cultivar virulence specificity is determined by avrBs3 homolog avrXg1. Phytopathology 99:996-1004.

Barber, C. E., Tang, J. L., Feng, J. X., Pan, M. Q., Wilson, T. J., Slater, H., Dow, J. M., Williams, P., and Daniels, M. J. 1997. A novel regulatory system required for pathogenicity of Xanthomonas campestris is mediated by a small diffusible signal molecule. Mol. Microbiol. 24:555-566.

Büttner, D., and Bonas, U. 2010. Regulation and secretion of Xanthomonas virulence factors. FEMS Microbiol. Rev. 34:107-133.

Cai, Z., Yuan, Z. H., Zhang, H., Pan, Y., Wu, Y., Tian, X. Q., Wang, F. F., Wang, L., and Qian, W. 2017. Fatty acid DSF binds and allosterically activates histidine kinase RpfC of phytopathogenic bacterium Xanthomonas campestris pv. campestris to regulate quorum-sensing and virulence. PLoS Pathog 13:e1006304.

Chatnaparat, T., Prathuangwong, S., Ionescu, M., and Lindow, S. E. 2012. XagR, a LuxR homolog, contributes to the virulence of Xanthomonas axonopodis pv. glycines to soybean. Mol. Plant-Microbe Interact. 25: 1104-1117.

Chin, K. H., Lee, Y. C., Tu, Z. L., Chen, C. H., Tseng, Y. H., Yang, J. M., Ryan, R. P., McCarthy, Y., Dow, J. M., Wang, A. H., and Chou, S. H. 2010. The cAMP receptor-like protein Clp is a novel c-di-GMP receptor linking cell-cell signaling to virulence gene expression in Xanthomonas campestris. J. Mol. Biol. 396:646-662.

Danhorn, T., and Fuqua, C. 2007. Biofilm formation by plant-associated bacteria. Annu. Rev. Microbiol. 61:401-422.

Davies, D. G., Parsek, M. R., Pearson, J. P., Iglewski, B. H., Costerton, J. W., and Greenberg, E. P. 1998. The involvement of cell-to-cell signals in the development of a bacterial biofilm. Science 280:295-298.

de Crecy-Lagard, V., Glaser, P., Lejeune, P., Sismeiro, O., Barber, C. E., Daniels, M. J., and Danchin, A. 1990. A Xanthomonas campestris pv. campestris protein similar to catabolite activation factor is involved in regulation of phytopathogenicity. J. Bacteriol. 172:5877-5883.

Dow, J. M., Crossman, L., Findlay, K., He, Y. Q., Feng, J. X., and Tang, J. L. 2003. Biofilm dispersal in Xanthomonas campestris is controlled by cellcell signaling and is required for full virulence to plants. Proc. Natl. Acad. Sci. USA 100:10995-11000.

Guan, W. J., Wu, M. S., and He, C. Y. 2009. Molecular identification and functional analysis of Clpxoo, a homologue to the nucleotide receptor protein in Xanthomonas oryzae pv. oryzae. Wei Sheng Wu Xue Bao 49:32-37.

Guo, W., Zou, L. F., Cai, L. L., and Chen, G. Y. 2015. Glucose-6-phosphate dehydrogenase is required for extracellular polysaccharide production, cell motility and the full virulence of Xanthomonas oryzae pv. oryzicola. Microb. Pathog. 78:87-94.

Guo, W., Zou, L. F., Ji, Z. Y., Cai, L. L., and Chen, G. Y. 2017. Glucose 6-phosphate isomerase (Pgi) is required for extracellular polysaccharide biosynthesis, DSF signals production and full virulence of Xanthomonas oryzae pv. oryzicola in rice. Physiol. Mol. Plant Pathol. 100:209-219.

Guo, W., Zou, L. F., Li, Y. R., Cui, Y. P., Ji, Z. Y., Cai, L. L., Zou, H. S., Hutchins, W. C., Yang, C. H., and Chen, G. Y. 2012a. Fructose-bisphophate aldolase exhibits functional roles between carbon metabolism and the hrp system in rice pathogen Xanthomonas oryzae pv. oryzicola. PLoS One 7: e31855.

Guo, Y., Figueiredo, F., Jones, J., and Wang, N. 2011. HrpG and HrpX play global roles in coordinating different virulence traits of Xanthomonas axonopodis pv. citri. Mol. Plant-Microbe Interact. 24:649-661.

Guo, Y. P., Zhang, Y. P., Li, J. L., and Wang, N. 2012b. Diffusible signal factormediated quorum sensing plays a central role in coordinating gene expression of Xanthomonas citri subsp. citri. Mol. Plant-Microbe Interact. 25:165-179.

He, Y. W., Boon, C., Zhou, L., and Zhang, L. H. 2009. Co-regulation of Xanthomonas campestris virulence by quorum sensing and a novel twocomponent regulatory system RavS/RavR. Mol. Microbiol. 71:1464-1476.

He, Y. W., Ng, A. Y., Xu, M., Lin, K., Wang, L. H., Dong, Y. H., and Zhang, L. H. 2007. Xanthomonas campestris cell-cell communication involves a putative nucleotide receptor protein $\mathrm{Clp}$ and a hierarchical signalling network. Mol. Microbiol. 64:281-292.

He, Y. W., Xu, M., Lin, K., Ng, Y. J., Wen, C. M., Wang, L. H., Liu, Z. D., Zhang, H. B., Dong, Y. H., Dow, J. M., and Zhang, L. H. 2006. Genome scale analysis of diffusible signal factor regulon in Xanthomonas campestris pv. campestris: Identification of novel cell-cell communication-dependent genes and functions. Mol. Microbiol. 59:610-622.

He, Y. W., and Zhang, L. H. 2008. Quorum sensing and virulence regulation in Xanthomonas campestris. FEMS Microbiol. Rev. 32:842-857.

Islam, M. R., Kabir, M. S., Hirata, H., Tsuge, S., and Tsuyumu, S. 2009. A leucine-rich protein, $\mathrm{LrpX}$, is a new regulator of hrp genes in Xanthomonas oryzae pv. oryzae. J. Gen. Plant Pathol. 75:66-71.
Jiang, J., Zou, H. S., Li, Y. R., and Chen, G. Y. 2009. Expression of the $h r c C$, $h r p E$ and $h p a 3$ genes is not regulated by the $h r p G$ and $h r p X$ genes in a rice pathogen Xanthomonas oryzae pv. oryzicola. Wei Sheng Wu Xue Bao 49: 1018-1025.

Leduc, J. L., and Roberts, G. P. 2009. Cyclic di-GMP allosterically inhibits the CRP-like protein (Clp) of Xanthomonas axonopodis pv. citri. J. Bacteriol. 191:7121-7122.

Lee, C.-K., Lee, B.-M., and Cho, J.-Y. 2008. Identification of new internal promoters of the Xanthomonas oryzae pathovar oryzae gum gene cluster. Biotechnol. Lett. 30:521-527.

Li, Y. R., Zou, H. S., Che, Y. Z., Cui, Y. P., Guo, W., Zou, L. F., Chatterjee, S., Biddle, E. M., Yang, C. H., and Chen, G. Y. 2011. A novel regulatory role of HrpD6 in regulating hrp-hrc-hpa genes in Xanthomonas oryzae pv. oryzicola. Mol. Plant-Microbe Interact. 24:1086-1101.

Lu, G. T., Tang, Y. Q., Li, C. Y., Li, R. F., An, S. Q., Feng, J. X., He, Y. Q., Jiang, B. L., Tang, D. J., and Tang, J. L. 2009a. An adenosine kinase exists in Xanthomonas campestris pathovar campestris and is involved in extracellular polysaccharide production, cell motility, and virulence. J. Bacteriol. 191:3639-3648.

Lu, G. T., Xie, J. R., Chen, L., Hu, J. R., An, S. Q., Su, H. Z., Feng, J. X., He, Y. Q., Jiang, B. L., Tang, D. J., and Tang, J. L. 2009b. Glyceraldehyde-3phosphate dehydrogenase of Xanthomonas campestris pv. campestris is required for extracellular polysaccharide production and full virulence. Microbiology 155:1602-1612.

Lu, Y., Rashidul, I. M., Hirata, H., and Tsuyumu, S. 2011. KdgR, an ICIR family transcriptional regulator, inhibits virulence mainly by repression of hrp genes in Xanthomonas oryzae pv. oryzae. J. Bacteriol. 193: 6674-6682.

Malamud, F., Torres, P. S., Roeschlin, R., Rigano, L. A., Enrique, R., Bonomi, H. R., Castagnaro, A. P., Marano, M. R., and Vojnov, A. A. 2011. The Xanthomonas axonopodis pv. citri flagellum is required for mature biofilm and canker development. Microbiology 157:819-829.

Mellgren, E. M., Kloek, A. P., and Kunkel, B. N. 2009. Mqo, a tricarboxylic acid cycle enzyme, is required for virulence of Pseudomonas syringae pv. tomato strain DC3000 on Arabidopsis thaliana. J. Bacteriol. 191: 3132-3141.

Nesper, J., Hug, I., Kato, S., Hee, C. S., Habazettl, J. M., Manfredi, P., Grzesiek, S., Schirmer, T., Emonet, T., and Jenal, U. 2017. Cyclic di-GMP differentially tunes a bacterial flagellar motor through a novel class of CheY-like regulators. eLife 6:e28842.

O'Connell, A., An, S. Q., McCarthy, Y., Schulte, F., Niehaus, K., He, Y. Q., Tang, J. L., Ryan, R. P., and Dow, J. M. 2013. Proteomics analysis of the regulatory role of Rpf/DSF cell-to-cell signaling system in the virulence of Xanthomonas campestris. Mol. Plant-Microbe Interact. 26:1131-1137.

Ryan, R. P., An, S. Q., Allan, J. H., McCarthy, Y., and Dow, J. M. 2015. The DSF family of cell-cell signals: An expanding class of bacterial virulence regulators. PLoS Pathog 11:e1004986.

Ryan, R. P., Fouhy, Y., Lucey, J. F., Crossman, L. C., Spiro, S., He, Y. W., Zhang, L. H., Heeb, S., Cámara, M., Williams, P., and Dow, J. M. 2006. Cell-cell signaling in Xanthomonas campestris involves an HD-GYP domain protein that functions in cyclic di-GMP turnover. Proc. Natl. Acad. Sci. USA 103:6712-6717.

Ryan, R. P., Fouhy, Y., Lucey, J. F., Jiang, B. L., He, Y. Q., Feng, J. X., Tang, J. L., and Dow, J. M. 2007. Cyclic di-GMP signalling in the virulence and environmental adaptation of Xanthomonas campestris. Mol. Microbiol. 63: $429-442$

Schröter, K., Flaschel, E., Pühler, A., and Becker, A. 2001. Xanthomonas campestris pv. campestris secretes the endoglucanases ENGXCA and ENGXCB: Construction of an endoglucanase-deficient mutant for industrial xanthan production. Appl. Microbiol. Biotechnol. 55:727-733.

Slater, H., Alvarez-Morales, A., Barber, C. E., Daniels, M. J., and Dow, J. M. 2000. A two-component system involving an HD-GYP domain protein links cell-cell signalling to pathogenicity gene expression in Xanthomonas campestris. Mol. Microbiol. 38:986-1003.

Tang, D. J., He, Y. Q., Feng, J. X., He, B. R., Jiang, B. L., Lu, G. T., Chen, B., and Tang, J. L. 2005. Xanthomonas campestris pv. campestris possesses a single gluconeogenic pathway that is required for virulence. J. Bacteriol. 187:6231-6237.

Tans-Kersten, J., Brown, D., and Allen, C. 2004. Swimming motility, a virulence trait of Ralstonia solanacearum, is regulated by FlhDC and the plant host environment. Mol. Plant-Microbe Interact. 17:686-695.

Tao, F., He, Y. W., Wu, D. H., Swarup, S., and Zhang, L. H. 2010. The cyclic nucleotide monophosphate domain of Xanthomonas campestris global regulator Clp defines a new class of cyclic di-GMP effectors. J. Bacteriol. 192:1020-1029.

Thowthampitak, J., Shaffer, B. T., Prathuangwong, S., and Loper, J. E. 2008. Role of $r p f F$ in virulence and exoenzyme production of Xanthomonas axonopodis pv. glycines, the causal agent of bacterial pustule of soybean. Phytopathology 98:1252-1260. 
Tian, F., Yu, C., Li, H. Y., Wu, X. L., Li, B., Chen, H. M., Wu, M. S., and He, C. Y. 2015. Alternative sigma factor RpoN2 is required for flagellar motility and full virulence of Xanthomonas oryzae pv. oryzae. Microbiol. Res. 170: 177-183.

Vojnov, A. A., Slater, H., Daniels, M. J., and Dow, J. M. 2001. Expression of the gum operon directing xanthan biosynthesis in Xanthomonas campestris and its regulation in planta. Mol. Plant-Microbe Interact. 14:768-774.

Wang, L. F., Rong, W., and He, C. Z. 2008. Two Xanthomonas extracellular polygalacturonases, PghAxc and PghBxc, are regulated by type III secretion regulators HrpX and HrpG and are required for virulence. Mol. PlantMicrobe Interact. 21:555-563.

Wang, L. H., He, Y. W., Gao, Y. F., Wu, J. E., Dong, Y. H., He, C. Z., Wang, S. X., Weng, L. X., Xu, J. L., Tay, L., Fang, R. X., and Zhang, L. H. 2004. A bacterial cell-cell communication signal with cross-kingdom structural analogues. Mol. Microbiol. 51:903-912.

Xia, T., Li, Y. J., Sun, D. L., Zhuo, T., Fan, X. J., and Zou, H. S. 2016. Identification of an extracellular endoglucanase that is required for full virulence in Xanthomonas citri subsp. citri. PLoS One 11:e156458.

Yang, F. H., Qian, S. S., Tian, F., Chen, H. M., Hutchins, W., Yang, C. H., and He, C. Y. 2016. The GGDEF-domain protein GdpX1 attenuates motility, exopolysaccharide production and virulence in Xanthomonas oryzae pv. oryzae. J. Appl. Microbiol. 120:1646-1657.

Yang, W. F., Liu, Y., Chen, L., Gao, T. C., Hu, B. S., Zhang, D. F., and Liu, F. Q. 2007. Zinc uptake regulator (zur) gene involved in zinc homeostasis and virulence of Xanthomonas oryzae pv. oryzae in rice. Curr. Microbiol. 54:307-314.
Yu, X., Liang, X., Liu, K., Dong, W., Wang, J., and Zhou, M. G. 2015. The thiG gene is required for full virulence of Xanthomonas oryzae pv. oryzae by preventing cell aggregation. PLoS One 10:e134237.

Yun, M. H., Torres, P. S., El Oirdi, M., Rigano, L. A., Gonzalez-Lamothe, R., Marano, M. R., Castagnaro, A. P., Dankert, M. A., Bouarab, K., and Vojnov, A. A. 2006. Xanthan induces plant susceptibility by suppressing callose deposition. Plant Physiol. 141:178-187.

Zhang, Y., Callaway, E. M., Jones, J. B., and Wilson, M. 2009. Visualisation of hrp gene expression in Xanthomonas euvesicatoria in the tomato phyllosphere. Eur. J. Plant Pathol. 124:379-390.

Zhang, Y. B., Wei, C., Jiang, W. D., Wang, L., Li, C. R., Wang, Y. Y., Dow, J. M., and Sun, W. X. 2013. The HD-GYP domain protein RpfG of Xanthomonas oryzae pv. oryzicola regulates synthesis of extracellular polysaccharides that contribute to biofilm formation and virulence on rice. PLoS One 8:e59428.

Zhang, Z., and Pierson, L. S. 2001. A second quorum-sensing system regulates cell surface properties but not phenazine antibiotic production in Pseudomonas aureofaciens. Appl. Environ. Microbiol. 67:4305-4315.

Zhou, L., Wang, X. Y., and He, Y. W. 2013. DSF signal-dependent quorum sensing in plant pathogenic bacteria Xanthomonas. Sci. Agric. Sin. 46: 2910-2922.

Zou, H. S., Song, X., Zou, L. F., Yuan, L., Li, Y. R., Guo, W., Che, Y. Z., Zhao, W. X., Duan, Y. P., and Chen, G. Y. 2012. EcpA, an extracellular protease, is a specific virulence factor required by Xanthomonas oryzae pv. oryzicola but not by X. oryzae pv. oryzae in rice. Microbiology 158:2372-2383. 